\title{
Review Article \\ MicroRNAs in Hepatocellular Carcinoma: Regulation, Function, and Clinical Implications
}

\author{
Jie Sun, Haiqi Lu, Xian Wang, and Hongchuan Jin \\ Laboratory of Cancer Epigenetics, Department of Medical Oncology, Biomedical Research Center, Sir Run Run Shaw Hospital, \\ School of Medicine, Zhejiang University, Hangzhou, Zhejiang 310016, China
}

Correspondence should be addressed to Hongchuan Jin; jinhc@zju.edu.cn

Received 20 December 2012; Accepted 13 January 2013

Academic Editors: H. Grønbæk, M. Ladekarl, P.-D. Line, and P. Stål

Copyright (C) 2013 Jie Sun et al. This is an open access article distributed under the Creative Commons Attribution License, which permits unrestricted use, distribution, and reproduction in any medium, provided the original work is properly cited.

Hepatocellular carcinoma (HCC) is one of the most common cancers worldwide and the third cause of cancer-related death. Poor understanding of the mechanisms underlying the pathogenesis of HCC makes it difficult to be diagnosed and treated at early stage. MicroRNAs (miRNAs), a class of noncoding single-stranded RNAs of $\sim 22$ nucleotides in length, posttranscriptionally regulate gene expression by base pairing with the $3^{\prime}$ untranslated regions ( $3^{\prime}$ UTRs) of target messenger RNAs (mRNAs). Aberrant expression of miRNAs is found in many if not all cancers, and many deregulated miRNAs have been proved to play crucial roles in the initiation and progression of cancers by regulating the expression of various oncogenes or tumor suppressor genes. In this Paper, we will summarize the regulations and functions of miRNAs aberrantly expressed in HCC and discuss the potential application of miRNAs as diagnostic and prognostic biomarkers of $\mathrm{HCC}$ and their potential roles in the intervention of HCC.

\section{Introduction}

Being one of the most frequently diagnosed cancer worldwide, liver cancer is the second leading cause of cancerdeath in men and the sixth leading cause of cancer-related death in women [1]. Hepatocellular carcinoma (HCC), which account for $70 \%$ to $85 \%$ of the primary liver cancer cases, is rarely detected at its early stage, resulting in a short survival of few months [2]. About $90 \%$ of HCC cases arise from cirrhosis, which can be attributed to a wide range of factors including chronic viral hepatitis B or C (HBV or HCV) infections, alcohol abuse, nonalcoholic steatohepatitis (NASH), autoimmune hepatitis, primary biliary cirrhosis (PBC), and carcinogens exposure [3]. Considerable progresses on unraveling molecular mechanisms of HCC have been achieved recently, paving the way to the early detection and treatment of HCC.

MicroRNAs (miRNAs), a class of noncoding RNAs of $\sim 22$ nucleotides in length found both in plants and animals, have emerged as key posttranscriptional regulators of gene expression. It has been reported that many miRNAs are involved in human cancers, such as lung, breast, brain, liver, colorectal cancer, and leukemia. By targeting different genes in tumor development, miRNAs function as oncogenes or tumor suppressor genes. In this paper, we will summarize the process and the regulation of miRNA biogenesis, as well as our current knowledge about the biological relevance of miRNAs to HCC. Then, we will discuss the potential application of miRNAs as predictive, diagnostic, and prognostic biomarkers of HCC and their potential roles in cancer treatment.

Since the first discovered miRNA lin- 4 by Victor Ambros and his colleagues in Caenorhabditis elegans, more than 20,000 miRNAs have been identified in 193 species (Sanger miRBase release 19; http://www.mirbase.org/) [4]. miRNAs downregulate the expression of specific genes predominantly by base pairing with the $3^{\prime}$ untranslated regions ( $3^{\prime}$ UTRs) of target messenger RNAs (mRNAs), leading to translational inhibition, transcript destabilization, or both [5]. However, recently, findings indicate that miRNAs can also target the $5^{\prime}$ UTRs and coding regions of mRNAs $[6,7]$.

\section{The Biogenesis and Maturation of miRNAs}

In the nucleus, miRNAs genes are transcribed mainly by RNA polymerase II to generate primary miRNA transcripts (pri-miRNAs) that consist of one or more hairpin structures and finally produce one or more functional miRNAs [8]. 
Like protein-coding mRNAs, pri-miRNAs are usually capped at the $5^{\prime}$ end and polyadenylated at the $3^{\prime}$ end [9]. PrimiRNAs are then cleaved into $\sim 70$ nt hairpin-structured precursors (pre-miRNAs) with a $5^{\prime}$ phosphate and a $3^{\prime}$ 2nt overhang by a multiprotein complex called microprocessor which consists of Drosha, an RNase III enzyme, and DGCR8/Pasha, a double-stranded RNA-binding domain protein (dsRBD) [10]. The $3^{\prime} 2$ nt overhang is recognized by exportin-5 which transports pre-miRNAs to the cytoplasm via an Ran-GTP-dependent mechanism [11]. In the cytoplasm, pre-miRNAs are further processed to $\sim 22 \mathrm{nt}$ duplex by Dicer, a second RNase III endonuclease, and the dsRBD proteins TRBP/PACT [12]. Finally, the two miRNA strands are unwound, and one of the strands associates with an argonaute (AGO) protein within the RNA-induced silencing complex (RISC) where they regulate gene expression by mRNA degradation or translational repression, while another miRNA strand is quickly degraded [13] (Figure 1).

However, some miRNAs are not generated as described earlier. Mirtrons, for example, are produced from spliced introns as debranched introns that mimic the structural features of pre-miRNAs and enter to miRNA-processing pathway without Drosha-mediated cleavage [14]. In addition, some small nucleolar RNAs (snoRNAs) [15], transfer RNAs (tRNAs) [16], and endogenous short hairpin RNAs (shRNAs) [17] can also be processed into miRNA-like molecules in a microprocessor-independent manner.

2.1. Transcriptional Regulation of miRNAs. Transcription is an important step for miRNA expression regulation. Many characteristics of protein-coding genes, such as CpG islands, TATA box, TFIIB recognition, initiator elements, and histone modifications, also present in the promoters of miRNA genes [18], suggesting that the transcription regulators of miRNA like transcription factors (TFs), enhancers, and silencing elements may be similar to protein-coding genes. For instance, myogenin and myoblast determination 1 (MyoD1) can bind to the upstream of miR-1 and miR-133 loci and induce their transcription during myogenesis [19]. The proto-oncogene c-Myc which regulates $\sim 10-15 \%$ of human genes, binds to E-boxes and activates the transcription of miR-17-92 cluster [20], whereas the tumor suppressor p53 transactivates miR34 , which consequently suppresses the transcriptional activity of $\beta$-catenin [21].

Furthermore, miRNAs can autoregulate their own transcription by targeting some transcription factors to establish negative or positive feedback loops. For example, miR$133 \mathrm{~b}$ can regulate the maturation and function of midbrain dopaminergic neurons within a negative feedback circuit that includes the paired-like homeodomain transcription factor PITX3, the regulator and direct target of miR-133b [22]. Zincfinger E-box-binding protein ZEB1/SIP1 and the miRNA200 family represent another example of a complex doublenegative feedback regulation. miRNAs in miR-200 family play major roles in maintaining the epithelial phenotype by preventing the expression of ZEB1/SIP1, which can bind to the transcription start site of miR-200 family genes and repress their expression in mesenchymal cells [23].
Similar to protein-coding genes, the expression of miRNAs is also regulated by epigenetic mechanisms including DNA methylation and specific histone modifications. MiR127 , the first reported epigenetically regulated miRNA, is upregulated after treatment with demethylation agents 5aza in several cancer cell lines [24]. Moreover, inhibition of histone deacetylases (HDACs) results in transcriptional changes of $\sim 40 \%$ miRNAs genes [25]. For example, Sampath and his colleagues demonstrated that HDACs mediated the silencing of miR-15a, miR-16, and miR-29b in chronic lymphocytic leukemia [26].

2.2. Posttranscriptional Regulation of miRNAs. The expression of miRNAs is also controlled by the posttranscriptional maturation. For example, many pri-miRNAs are expressed during early mouse development but are not efficiently processed into mature miRNAs [27]. Moreover, the expression of individual miRNAs in a genomic cluster and processed from the same pri-miRNA is sometimes different at the mature form level [28].

The first step of miRNA processing is catalyzed in the nucleus by Drosha which is associated with DGCR8 and other proteins to form the microprocessor complex. Downregulation of the expression level of either Drosha or DGCR8 by RNAi leads to the reduction of both pre-miRNAs and mature miRNAs [10], and defects in the Drosha processing step contribute to widespread downregulation of miRNAs in primary tumors [27]. Some transcription factors, such as $\mathrm{p} 53$, receptor-regulated SMADs (R-Smads), and estrogen receptor $\alpha(\mathrm{ER} \alpha)$, can also participate in the rapid regulation of miRNA expression in response to extracellular stimuli by interacting with the DEAD-box RNA helicases p68 (DDX5) and/or p72 (DDX17). Both of them are components of the Drosha microprocessor complex [29-31].

The expression of let-7 miRNA controlled by Lin-28 shows a complicated model of posttranscriptional regulation of miRNA expression. The RNA-binding protein Lin28 selectively represses the let-7 family miRNAs biogenesis by binding to the terminal loop of pre- and pri-let-7 miRNAs [32]. During cell differentiation, the increase of mature let-7 results from the decrease of Lin28 [33]. Interestingly, Lin28 is downregulated by let-7 miRNAs, presenting a doublenegative feedback loop in cell differentiation [34].

\section{Involvement of miRNAs in HCC Development}

3.1. miRNAs and HCC-Associated Virus Infection. Chronic infections with either $\mathrm{HBV}$ or $\mathrm{HCV}$ increase the relative risk of liver cancer greatly. These chronic viral infections are present in more than $70 \%$ of HCC cases, and iatrogenic interventions against these viruses significantly reduce the risk of HCC development [35]. Cellular miRNAs have shown able to regulate $\mathrm{HBV}$ infection at the transcription level either by targeting cellular transcription factors required for $\mathrm{HBV}$ gene expression or by a directly binding to HBV transcripts [36]. For instance, miR-155 can downregulate HBV transcription by inhibiting the expression of CCAAT/enhancer-binding protein $(\mathrm{C} / \mathrm{EBP}-\beta)$, which binds to the Enhancer II, core 


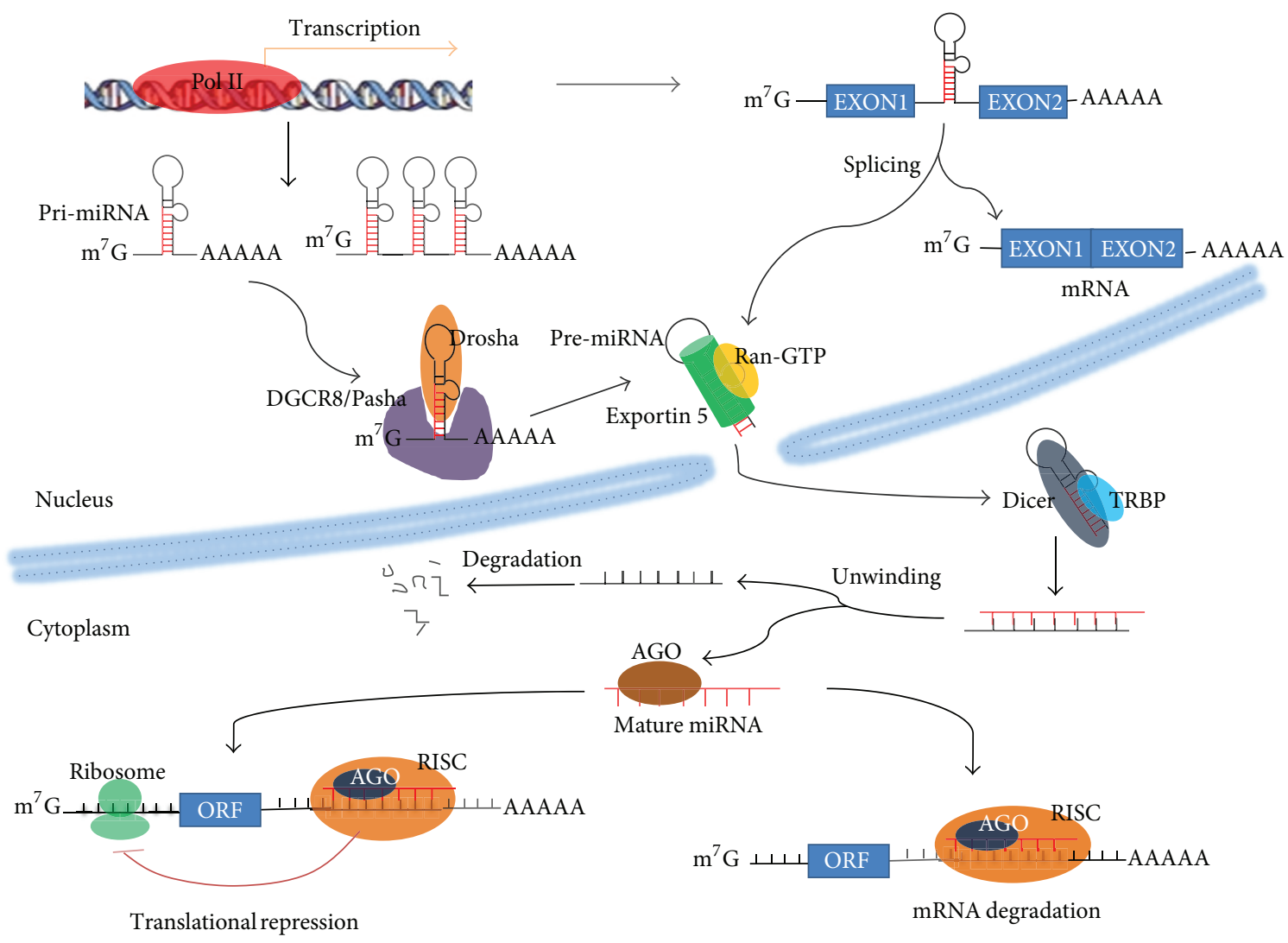

FIGURE 1: The biogenesis of microRNAs is summarized. Genes encoding microRNAs are transcribed mainly by Pol II (DNA-dependent RNA polymerase II) with the products as the pri-miRNAs that are processed into pre-miRNA by DGCR8/Drosha. Pre-miRNAs are exported into the cytoplasm where they are further converted into the mature forms by the TRBP/Dicer. Mature miRNAs bind to the target mRNAs to inhibit their expression. ORF: open-reading frame; RISC: RNA-induced silencing complex.

promoter and S-promoter of HBV cccDNA and activates the transcription of HBV cccDNA [37]. ER $\alpha$-targeting miR-18a is overexpressed in female HCC tissues, thus blocking ER $\alpha$ mediated suppression of HBV transcription [38]. This maybe explain why hepatocellular carcinoma predominantly affects men, with an incidence typically more than twofold higher in males than in females [1].

miRNAs can target important players in DNA methylation and histone modification that play crucial roles in HBV cccDNA transcription. For example, miR-152 and miR148a target DNA (cytosine-5)-methyltransferase 1 (DNMT-1) can methylate viral DNA and inhibit HBV replication [39]. Similarly, miR-1 regulates the expression of HDAC4 that can inhibit the replication of HBV [40]. On the other hand, HBVencoded proteins can influence cellular miRNA expression. Wang et al. compared the expression of 286 cellular miRNAs before and after the expression of HBx protein in HepG2 cells [41]. HBx was found to significantly upregulate the expression of 7 miRNAs but downregulate the expression of 11 cellular miRNAs such as the let-7 family miRNAs $[42,43]$. miRNAs in the let-7 family are commonly downregulated in various cancers including HCC and target and downregulate a number of proteins playing important roles in tumorigenesis and metastasis, such an Ras [44], high-mobility group AThook 2 (HMGA2) [45], myc [46], and signal transducer and activator of transcription 3 (STAT3) [41].
$\mathrm{HCV}$ infection is another independent risk factor for HCC. MiR-196 plays a protective role in HCV-induced HCC by upregulating heme oxygenase (decycling) 1 (HMOX1) expression and inhibiting HCV transcription [47].

3.2. miRNAs and Other Factors Related with HCC Development. Cirrhosis caused by chronic alcohol consumption is another risk factor of HCC especially in western countries. MiR-217 could promote ethanol-induced fat accumulation in hepatocytes by downregulating SIRT1 [48]. In a miRNA profiling study, Ladeiro et al. found that miR-126* was decreased in alcohol-related HCC [49]. Hepatic specimens from mice fed with an ethanol-containing diet indicated a decreased expression of miR-199 and miR-200, which are commonly downregulated in HCC [50].

miRNAs are also involved in the pathogenesis of NASH, an increasingly important risk factor for HCC in recent years. Unsaturated fatty acids have been shown to increase miR21 expression which downregulates the expression of tumor suppressor phosphatase and tensin homolog (PTEN) [51]. MiR-155 which targets another tumor suppressor C/EBP$\beta$ [52] is consistently upregulated in choline-deficient and amino acid-defined (CDAA) fed mice [37].

Carcinogen exposure induces malignant transformation often accompanied with miRNA deregulation. For instance, 
after continuously being exposed to a low concentration of microcystin-LR, a hepatocarcinogen, the human hepatic cell line WRL-68 showed aberrant miRAN expression including the up-regulation of oncogenic miRNA, miR-21, and miR221 [53]. Deregulation of miRNA expression also was found in the liver of mice treated with microcystin-LR and such deregulated miRNAs including miR-125b, miR-34a, and miR21 which play crucial roles in liver tumorigenesis [54]. Furthermore, miR-191 that was known to regulate a variety of oncogenic pathways was found to be upregulated by dioxin, a known liver carcinogen [55]. These miRNA alterations may be used to develop methods monitoring environmental carcinogens.

3.3. miRNAs Deregulated in HCC. Many reports had shown miRNA deregulation in HCCs and a list of aberrantly expressed miRNAs in HCC, has been summarized in Table 1. Like transcription factors, miRNAs play key roles in regulating diverse cellular pathways. Moreover, aberrant miRNA expression can be used as the signature to detect or characterize different type of HCC.

\section{Biological Relevance of Deregulated miRNAs in HCC}

miRNAs have been proved to exert their functions either as oncogenes or tumor suppressor genes in human cancers. Deregulated miRNAs in cancer cells have been found to contribute to most if not all hallmarks of malignant transformation including sustained proliferative signaling, resistant to cell death, immortality, angiogenesis, invasion, and metastasis [56].

4.1. Regulation of Cell Proliferation and Survival by Deregulated MicroRNAs in HCC. Under normal physiological conditions, cell proliferation and death are finely balanced by many regulators involved in cell cycle, growth, and apoptosis. However, these regulators are targeted by miRNAs deregulated in HCC.

Several miRNAs have been reported to be implicated in cell cycle regulation. For example, miR-26a and miR195 , which were found to be frequently downregulated in HCC, cooperate to overcome the G1/S cell cycle blockade through the repression of E2F expression $[57,58]$. In contrast, E2F1-targeting miR-106b and miR-93 promote the pathogenesis of HCC by inhibiting E2F1-induced apoptosis [59]. As a downstream target of tumor suppressor p53, miR-34a functions as a link between p53 signaling and the cell cycle regulation by targeting cyclin $\mathrm{D} 1$, cyclin-dependent kinase 4 (CDK4) and CDK2 in HCC [60]. MiR-221 and miR222 have been reported to target CDKN1B/p27/Kipl and CDKN1C/p57/Kip2, while miR-223 participates in regulating the $\mathrm{G} 2 / \mathrm{M}$ transition mediated by stathmin-1 [61]. In addition, miR-193b and miR-250b can suppress colony forming ability in vitro and tumorigenesis in vivo by inducing cyclin D1mediated G1 phase arrest $[62,63]$.

A number of deregulated miRNAs are involved in the regulation of apoptosis. Bcl-2-modifying factor (Bmf) and p53 upregulated modulator of apoptosis (PUMA), two members of pro-apoptotic Bcl-2 family, are downregulated by miR-221 [64, 65]. The expression of three members of miR106b-25 cluster, miR-25, miR-93, and miR-106b, is inversely correlated with Bim expression [59]. Conversely, the antiapoptotic members, B-cell lymphoma 2 (Bcl-2), induced myeloid leukemia cell differentiation protein (Mcl-1), and Bcl-2-like protein $2(\mathrm{Bcl}-\mathrm{w})$, are the targets of miR-125b [66, 67], miR-224 [68], miR-29 [69], miR-101 [70], and miR122 [71]. Besides cell cycle regulation, miR-221 and miR222 enhance the resistance to TRAIL-induced apoptosis by negatively regulating PTEN and metalloproteinase inhibitor 3 (TIMP3) [72]. Furthermore, let-7 miRNAs negatively regulate $\mathrm{B}$-cell lymphoma-extra large $(\mathrm{Bcl}-\mathrm{xL})$ expression and enhance the sensitivity of HCC cells to apoptosis induced by Mcl-1- targeting anticancer drugs [73].

The activation of tyrosine kinase receptors (RTKs) initiates a signaling cascade that eventually leads to cell proliferation and survival. Many miRNAs have been shown to regulate the expression of proteins in RTK pathways. PTEN is downregulated by many miRNAs upregulated in HCC, such as miR-216a [74], miR-21 [75], miR-148a [76], miR221/222 [72], miR-519d [77], and miR-29a [78], leading to the activation of $\mathrm{PI} 3 \mathrm{~K} / \mathrm{AKT} / \mathrm{mTOR}$ pathway. In addition, miR-7 regulates $\mathrm{PI} 3 \mathrm{~K} / \mathrm{Akt}$ pathway by targeting to phosphoinositide 3-kinase (PIK3CD), mTOR, and p70S6K [79]. Restoring the expression of mTOR- and c-Met-targeting miR-199a-3p in HCC cells led to G1 arrest, reduced invasive capability, enhanced susceptibility to hypoxia, and increased sensitivity to doxorubicin-induced apoptosis [80]. c-Met can also be suppressed by other miRNAs including miR-23b [81], miR1 [82], miR-198 [83], miR-449 [84], and miR-34a [85].

4.2. Regulation of Angiogenesis and Metastasis by Deregulated miRNAs in HCC. Angiogenesis and metastasis play important roles in the progression and recurrence of HCC. Aberrant angiogenesis and metastasis can be triggered by various stimuli from tumor microenvironment or/and intracellular signaling molecules that are subjected to the regulation of miRNAs. In an effort to identify potential miRNAs involved in the regulation of angiogenesis and metastasis, Santhekadur and colleagues unraveled a linear pathway in which staphylococcal-nuclease-domain-containing-protein1 (SND1-) induced activation of NF- $\kappa \mathrm{B}$ resulted in miR221 expression and subsequent induction of angiogenic factors angiogenin and chemokine (C-X-C motif) ligand 16 (CXCL16). Inhibition of either of these components resulted in significant inhibition of SND1-induced angiogenesis [86]. Hepatoma-derived growth factor (HDGF), a promoter of tumor angiogenesis, is a downstream target of miR-214 that is downregulated in HCC [87]. miR-122 can inhibit angiogenesis and intrahepatic metastasis by suppressing the expression of tumor necrosis factor- $\alpha$-converting enzyme (TACE) [88]. In addition, downregulation of miR-29b and miR-125b in HCC contribute to the increased angiogenesis and metastasis through upregulating the expression of matrix metalloproteinase 2 (MMP2) and placenta-growth factor (PGF) $[89,90]$. 
TABLE 1: MiRNAs deregulated in hepatocellular carcinoma (HCC).

\begin{tabular}{|c|c|c|c|c|c|}
\hline miRNA & $\begin{array}{c}\text { Expression in } \\
\text { HCC }\end{array}$ & Regulator & Target & Involvement in cellular processes & References \\
\hline Let-7a & Down & $\mathrm{c}-\mathrm{myc}$ & Caspase-3 & apoptosis; proliferation & {$[42,91]$} \\
\hline Let-7b & Down & & HMGA2 & apoptosis; proliferation & {$[92]$} \\
\hline Let-7c & Down & EZH2; PPARalpha & Bcl-xL; c-myc & apoptosis; proliferation; cell growth & {$[43,93,94]$} \\
\hline Let-7d & Down & $\mathrm{c}-\mathrm{myc}$ & & apoptosis; proliferation & {$[42]$} \\
\hline Let-7f-1 & Down & $\mathrm{c}-\mathrm{myc}$ & & apoptosis; proliferation & {$[42]$} \\
\hline Let-7g & Down & & $\begin{array}{c}\text { Bcl-xL; COL1A2; c-Myc; } \\
\text { p16(INK4A) }\end{array}$ & apoptosis; metastasis & {$[73,95,96]$} \\
\hline miR-1 & Down & & ET-1; & proliferation & {$[97]$} \\
\hline miR-101 & Down & $\mathrm{EZH} 2$ & $\begin{array}{l}\text { Mcl-1; EZH2; EED; } \\
\text { DNMT3A; SOX9 }\end{array}$ & $\begin{array}{c}\text { Colon formation; apoptosis; DNA } \\
\text { methylation }\end{array}$ & $\begin{array}{l}{[43,70,98} \\
\quad 99]\end{array}$ \\
\hline miR-122 & Down & PPFP & Bcl-w; ADAM17; Wnt1 & apoptosis; metastasis; Angiogenesis; & $\begin{array}{c}{[71,88} \\
100,101]\end{array}$ \\
\hline miR-124 & Down & & PIK3CA & proliferation & {$[102]$} \\
\hline miR-125a & Down & & MMP11; VEGF-A; SIRT7 & proliferation; metastasis; metabolism & {$[103,104]$} \\
\hline miR-125b & Down & $\mathrm{EZH} 2 ; \mathrm{p} 53$ & $\begin{array}{l}\text { LIN28B2; PIGF; Bcl-2; } \\
\text { Mcl-1; Bcl-w; SUV39H1; } \\
\text { SIRT7 }\end{array}$ & $\begin{array}{l}\text { proliferation; metastasis; angiogenesis; } \\
\text { apoptosis; histone modification }\end{array}$ & $\begin{array}{c}{[43,66,90,} \\
104-106]\end{array}$ \\
\hline miR-139 & Down & $\mathrm{EZH} 2$ & ROCK2; c-Fos & metastasis & $\begin{array}{c}{[43,107,} \\
108]\end{array}$ \\
\hline $\operatorname{miR}-138$ & Down & & CCND3 & Cell cycle & {$[109]$} \\
\hline $\operatorname{miR}-145$ & Down & & IRS1; IRS2; Oct4 & Cell growth; tumorigenesis & {$[110,111]$} \\
\hline miR-195 & Down & & $\begin{array}{l}\text { cyclin D1; CDK6; E2F3; } \\
\text { LATS2 }\end{array}$ & tumorigenesis; cell cycle; apoptosis & {$[57,112]$} \\
\hline miR-199a-3p & Down & & mTOR; PAK4; caveolin-2 & drug resistance; Cell growth; & $\begin{array}{c}{[80,113,} \\
114]\end{array}$ \\
\hline miR-199a-5p & Down & & DDR1; ATG7 & invasion; autophagy & {$[115,116]$} \\
\hline miR-200a & Down & HDAC4 & HDAC4 & proliferation; metastasis; & {$[117]$} \\
\hline miR-203 & Down & & Surviving & proliferation & {$[118]$} \\
\hline $\operatorname{miR}-214$ & Down & & $\beta$-catenin; HDGF & Cell growth; metastasis; angiogenesis & $\begin{array}{l}{[87,119,} \\
120]\end{array}$ \\
\hline miR-219-5p & Down & & GPC3 & proliferation & {$[121]$} \\
\hline miR-223 & Down & & STMN1 & proliferation & {$[61]$} \\
\hline $\mathrm{miR}-26 \mathrm{a} / \mathrm{b}$ & Down & $\mathrm{c}-\mathrm{myc}$ & CDK6; cyclin E1 & Cell cycle & {$[122]$} \\
\hline miR-29a & Down & & SPARC & proliferation & {$[123]$} \\
\hline miR-34a & Down & TGF- $\beta$ & c-Met; CCL22 & metastasis & {$[85,124]$} \\
\hline miR-375 & Down & & ATG7 & Autophagy & {$[125]$} \\
\hline miR-376a & Down & & PIK3R1 & apoptosis; proliferation & {$[126]$} \\
\hline miR-449 & Down & & c-Met & proliferation; apoptosis & {$[84]$} \\
\hline miR-450a & Down & & DNMT3a & proliferation & {$[127]$} \\
\hline miR-520b & Down & & MEKK2; cyclin D1 & Cell growth; proliferation & {$[63]$} \\
\hline miR-7 & Down & & PIK3CD; mTOR; p70S6K & Tumorigenesis; metastasis & {$[79]$} \\
\hline miR-10a & Up & & EphA4; CADM1 & EMT; metastasis & {$[128,129]$} \\
\hline miR-130a & Up & & RUNX3 & drug resistance & {$[130]$} \\
\hline $\operatorname{miR}-135 a$ & Up & FOXM1 & MTSS1 & metastasis & {$[131]$} \\
\hline miR-143 & Up & $N F-\kappa B$ & FNDC3B & metastasis & {$[132]$} \\
\hline miR-155 & Up & $\mathrm{NF}-\kappa \mathrm{B}$ & APC & proliferation; Tumorigenesis & [133] \\
\hline miR-18a & Up & & ERalpha & proliferation & {$[38]$} \\
\hline
\end{tabular}


TABle 1: Continued.

\begin{tabular}{|c|c|c|c|c|c|}
\hline miRNA & $\begin{array}{c}\text { Expression in } \\
\text { HCC }\end{array}$ & Regulator & Target & Involvement in cellular processes & References \\
\hline miR-181b & $\mathrm{Up}$ & Smad4 & TIMP3 & Cell growth; tumorigenesis; metastasis & {$[134]$} \\
\hline miR-182 & Up & & MTSS1 & metastasis & [135] \\
\hline $\operatorname{miR}-21$ & Up & & PTEN; RHOB; PDCD4 & metastasis; drug resistance & $\begin{array}{c}{[75,136-} \\
138]\end{array}$ \\
\hline $\operatorname{miR}-210$ & Up & & VMP1; AIFM3 & metastasis; apoptosis; proliferation & {$[139,140]$} \\
\hline miR-216a & Up & Androgen receptor & TSLC1 & tumorigenesis & {$[141]$} \\
\hline $\operatorname{miR}-221$ & Up & SND1 & $\begin{array}{c}\text { Bmf; CDKN1B/p27; } \\
\text { CDKN1C/p57; DDIT4; } \\
\text { Arnt }\end{array}$ & apoptosis; proliferation; Angiogenesis & $\begin{array}{c}{[64,86,} \\
142-144]\end{array}$ \\
\hline $\operatorname{miR}-224$ & Up & $\begin{array}{l}\text { HDAC1; HDAC3; } \\
\text { EP300; NF } \kappa \mathrm{B}\end{array}$ & $\begin{array}{l}\text { RKIP; CDC42; CDH1; } \\
\text { PAK2; BCL-2; MAPK1; } \\
\text { API-5 }\end{array}$ & Metastasis; proliferation; apoptosis & $\begin{array}{c}{[68,145-} \\
148]\end{array}$ \\
\hline miR-23a & Up & Stat3 & PGC-1 $\alpha$; G6PC & Gluconeogenesis & {$[149]$} \\
\hline $\operatorname{miR}-373$ & Up & & PPP6C & Cell cycle & {$[150]$} \\
\hline miR-301a & Up & & Gax & metastasis & {$[151]$} \\
\hline $\operatorname{miR}-490-3 p$ & Up & & ERGIC3 & EMT & {$[152]$} \\
\hline miR-519d & Up & p53 & $\begin{array}{c}\text { CDKN1A/p21; PTEN; } \\
\text { AKT3; TIMP2 }\end{array}$ & proliferation; invasion; apoptosis & {$[77]$} \\
\hline MiR-550a & Up & & CPEB4 & Metastasis & {$[153]$} \\
\hline miR-590-5p & Up & & TGF-beta RII & Metastasis; proliferation & {$[154]$} \\
\hline miR-615-5p & Up & & IGF-II & Cell growth; migration & {$[155]$} \\
\hline miRNA-657 & $\mathrm{Up}$ & & TLE1 & proliferation & [156] \\
\hline
\end{tabular}

TABLE 2: SNPs in miRNAs and their target genes and the association with risk of HCC.

\begin{tabular}{|c|c|c|c|}
\hline & Polymorphisms ID & Gene & Association with HCC Risk \\
\hline \multirow{9}{*}{ Polymorphisms in miRNA genes } & rs3859501 & miR-371-373 & Negative [157] \\
\hline & rs7536540 & miR-101-1 & Positive [158] \\
\hline & rs12375841 & miR-101-2 & Positive [158] \\
\hline & rs2292832 & miR-149c & Negative [159] \\
\hline & rs3746444 & miR-499a & $\begin{array}{c}\text { No association [160] } \\
\text { Negative [159] } \\
\text { Positive [161] }\end{array}$ \\
\hline & rs4938723 & $\mathrm{miR}-34 \mathrm{~b} / \mathrm{c}$ & Positive [162] \\
\hline & rs11614913 & miR-196a-2 & $\begin{array}{c}\text { Positive [163-165] } \\
\text { No association [159] }\end{array}$ \\
\hline & rs2910164 & miR-146a & No association $[159,166]$ \\
\hline & rs999885 & miR-106b-25 cluster & Positive [167] \\
\hline \multirow{5}{*}{ Polymorphisms in miRNA target genes } & rs3783553 & IL-1alpha & Positive [168] \\
\hline & rs16405 & betaTrCP & Positive [169] \\
\hline & rs17875871 & IFNAR1 & Positive [170] \\
\hline & rs6147150 & ErbB4 & Positive [171] \\
\hline & rs3917 & COL1A2 & Positive [172] \\
\hline
\end{tabular}


miRNAs are also involved in the metastasis through the regulation of epithelial to mesenchymal transition (EMT). For example, miR-10a promotes metastasis by regulating ephrin-type-A-receptor-4-(EphA4-) mediated EMT in HCC [89]. By downregulating Rho-associated coiled-coil containing protein kinase 2 (ROCK2) and histone-lysine Nmethyltransferase (EZH2), miR-124 represses cytoskeleton reorganization and EMT, ultimately inhibiting the invasive and/or metastatic potential of HCC [173]. Meanwhile, p53 upregulates miR-200 and miR-192 family miRNAs to inhibit ZEB1/2-midated EMT [174]. More miRNAs involved in metastasis of HCC and their regulators and targets are listed in Table 1.

\section{Clinical Potentials of miRNAs in HCC}

5.1. miRNAs Related Genetic Variations and HCC Risk Prediction. Single nucleotide polymorphisms (SNPs) in some miRNAs or their targets are associated with risk of HCC (Table 2). Since the binding of a miRNA to its target mRNA is largely attributed to the seed sequence, even one nucleotide variation in the seed sequence would result in dramatic changes in the efficiency of miRNA-gene interaction. For instance, the rs11614913 $(\mathrm{C} \rightarrow \mathrm{T})$ SNP in miR-196a-2 is positively associated with HCC susceptibility in Chinese $[163,164]$ and Turkish [165]. The "TTCA" insertion (rs3783553) disrupts the binding site in the $3^{\prime}$-UTR of IL-lalpha for miR-122 and miR-378, leading to the up-regulation of IL-1alpha expression and the promotion of HCC development [168]. However, conflicted results were achieved from three studies on the association between polymorphism of miR-499a and HCC risk in three populations with different ethnical backgrounds [159-161]. Therefore, polymorphisms of miRNAs or the $3^{\prime}$-UTR of their targets may be useful in HCC risk prediction.

5.2. miRNAs as Diagnostic and Prognostic Markers of HCC. The differential expression of miRNAs in hepatocellular carcinoma cells compared with their expression in normal hepatocytes indicates potential values of miRNA detection in HCC diagnosis and prognosis predication. For example, HCCs can be divided into three main clusters based on miRNA profiling [175]. Using a human miRNA microarray, Murakami and colleagues identified three significantly upregulated miRNAs and five downregulated ones in 25 HCC tissues compared with the nontumorous samples. The algorithm based on the detection of these deregulated miRNAs showed an overall prediction accuracy of $97.8 \%$ for HCC diagnosis. In addition, the expression levels of miR692, miR620, and miR618 were inversely correlated with the degree of HCC differentiation [176]. Downregulation of miR-139 was associated significantly with poor prognosis of patients and features of metastatic tumors including venous invasion, microsatellite formation, absence of tumor encapsulation, and reduced differentiation [107]. Inversely, high levels of miR-222 and C19MC miRNA were correlated with poor clinicopathological features such as increased risk of tumor recurrence and shorter overall survival $[177,178]$.
TABLE 3: Clinical relevance of deregulated microRNAs in HCC.

\begin{tabular}{|c|c|c|}
\hline miRNA & $\begin{array}{l}\text { Expression } \\
\text { in HCC }\end{array}$ & Clinical relevance \\
\hline miR-122 [179] & Down & Poor prognosis \\
\hline $\operatorname{miR}-124$ [173] & Down & $\begin{array}{l}\text { More aggressive and/or } \\
\text { poor prognosis }\end{array}$ \\
\hline miR-139 [107] & Down & Poor prognosis \\
\hline miR-145 [110] & Down & $\begin{array}{l}\text { Shorter disease-free } \\
\text { survival }\end{array}$ \\
\hline miR-199b [180] & Down & $\begin{array}{l}\text { Poorer overall survival, and } \\
\text { progression-free survival } \\
\text { rates }\end{array}$ \\
\hline $\operatorname{miR}-22[181]$ & Down & Poor survival \\
\hline miR-26 [182] & Down & Shorter overall survival \\
\hline $\operatorname{miR}-29$ [69] & Down & Worse disease-free survival \\
\hline miR-99a [183] & Down & Shorter survival \\
\hline let-7g [95] & Down & Poor survival \\
\hline miR-10b [129] & Up & Poor prognosis \\
\hline miR-125b [184] & Up & Good survival \\
\hline miR-135a [131] & Up & Poor prognosis \\
\hline miR-17-5p [185] & Up & $\begin{array}{l}\text { Worse Edmondson-Steiner } \\
\text { grade, vein invasion, } \\
\text { shortened overall survival } \\
\text { and disease-free survival }\end{array}$ \\
\hline serum miR-17-5p [186] & Up & Poor prognosis \\
\hline miR-155 [187] & Up & $\begin{array}{l}\text { Poorer recurrence-free } \\
\text { survival and overall } \\
\text { survival }\end{array}$ \\
\hline miR-182 [135] & Up & $\begin{array}{l}\text { Intrahepatic metastasis and } \\
\text { poor prognosis }\end{array}$ \\
\hline C19MC miRNA [177] & Up & $\begin{array}{l}\text { Increased risk of tumor } \\
\text { recurrence and shorter } \\
\text { overall survival time }\end{array}$ \\
\hline $\operatorname{miR}-21[188]$ & Up & Poor prognosis \\
\hline $\operatorname{miR}-221[188]$ & Up & Poor prognosis \\
\hline miR-222 [178] & Up & $\begin{array}{l}\text { Shorter disease-free } \\
\text { survival }\end{array}$ \\
\hline $\begin{array}{l}\text { 20-miRNA signature } \\
\text { [189] }\end{array}$ & Up/down & Metastases and recurrence \\
\hline $\begin{array}{l}\text { 19-miRNA signature } \\
{[190]}\end{array}$ & Down & Poor survival \\
\hline
\end{tabular}

More studies on the clinical value of miRNAs detection in HCC are summarized in Table 3.

Extracellular miRNAs in the circulation are stable, suggesting that miRNAs may serve as novel diagnostic markers [191]. Yamamoto et al. first reported an increased amount of miR-500 in the sera of HCC patients and its levels dropped to normal after the surgical treatment [192]. Interestingly, Shigoka and coworkers found that the relative amount of miR-92a in the plasmas from HCC patients, was decreased 
compared with that from the healthy donors [193]. In addition, serum level of miR-25, miR-375, and let-7f can clearly separate HCC cases from non-HCC controls, and miR-375 level alone displays the potential for the detection of HCC [194]. So far, more than 20 circulating miRNAs have been identified as diagnostic markers of HCC.

5.3. Potential Roles of miRNAs in HCC Therapy. As miRNAs have confirmed to function as oncogenes or tumor suppressors and exogenous expression of tumor suppressor miRNAs or inhibition of onco-miRs resulted in alterations in malignance phenotypes of HCC cells in vitro, it might be possible to use artificial miRNAs to repress cancer development in vivo. Indeed, systemic administration of miR-26a, a miRNA expressed at high levels in normal tissues but downregulated in HCC, resulted in the inhibition of cancer cell proliferation, induction of tumor-specific apoptosis, and dramatic protection from disease progression without toxicity in a mouse model of HCC. These findings suggest that delivery of miRNAs that are highly expressed in normal tissues but lost in disease cells may provide a general strategy for miRNA replacement therapies without significant toxicity [58]. Two independent studies had reported that decreasing miR-221 level led to prolonged survival or a reduction of the number and size of tumor nodules in mice HCC models by using antimiR-221 oligonucleotides or cholesterol-modified isoform of anti-miR-221 [195, 196]. On the other hand, restoration of miR-122 [88], miR-143 [132], and miR-124 [102] individually significantly inhibited tumorigenesis and metastasis in vivo.

Moreover, miRNAs have also been shown to influence sensitivity of tumors to anticancer drugs. HCC cells transfected with pre-miR-21 were resistant to the cytotoxicity induced by IFN- $\alpha / 5-\mathrm{FU}$, and miR-21 expression in clinical HCC specimens was associated with the poor clinical response to the IFN- $\alpha / 5-\mathrm{FU}$ combination therapy [136]. In addition, miR-181b can enhance resistance of HCC cells to doxorubicin [134]. Therefore, antagomirs targeting miR-21 or miR-181b might be useful in increasing drug efficacy. In contrast, restoration of miR-122 in HCC cells renders them more sensitive to adriamycin and vincristine through downregulating the expression of multidrug resistance (MDR) proteins [197].

\section{Conclusion and Perspectives}

Deregulation of miRNAs significantly contributes to the development of HCC. miRNAs mainly functions to downregulate the expression of targeted genes. However, they may have other yet unknown functions including the activation of gene transcription. The discovery of new types or novel functions of miRNAs provides us with more and deeper insights into the molecular mechanism underlying the pathogenesis of HCC. On the other hand, the miRNA expression profiles altered in HCC paves the way to early detection and treatment of HCC. With the advantage of target multiple genes simultaneously, miRNAs as therapeutic targets would be more efficient than other single-gene targeted therapeutics such as RNAi-based therapy, thus representing a new avenue for the development of anti-HCC treatments.

\section{Conflict of Interests}

The authors have no conflict of interests to claim.

\section{Acknowledgments}

This work was supported by the Department of Zhejiang Education (no. Y201121548), the Department of Zhejiang Healthcare (no. N20100555), the Program for Innovative Research Team in Zhejiang province (Grant no.: 2010R50046), and the National Natural Science Foundation of China (81071963 and 81071652).

\section{References}

[1] A. Jemal, F. Bray, M. M. Center, J. Ferlay, E. Ward, and D. Forman, "Global cancer statistics," CA: Cancer Journal for Clinicians, vol. 61, no. 2, pp. 69-90, 2011.

[2] J. F. Perz, G. L. Armstrong, L. A. Farrington, Y. J. F. Hutin, and B. P. Bell, "The contributions of hepatitis B virus and hepatitis $C$ virus infections to cirrhosis and primary liver cancer worldwide," Journal of Hepatology, vol. 45, no. 4, pp. 529-538, 2006.

[3] A. J. Sanyal, S. K. Yoon, and R. Lencioni, "The etiology of hepatocellular carcinoma and consequences for treatment," The Oncologist, vol. 15, pp. 14-22, 2010.

[4] R. C. Lee, R. L. Feinbaum, and V. Ambros, "The C. elegans heterochronic gene lin- 4 encodes small RNAs with antisense complementarity to lin-14," Cell, vol. 75, no. 5, pp. 843-854, 1993.

[5] W. Filipowicz, S. N. Bhattacharyya, and N. Sonenberg, "Mechanisms of post-transcriptional regulation by microRNAs: are the answers in sight?" Nature Reviews Genetics, vol. 9, no. 2, pp. 102 $114,2008$.

[6] U. A. Ørom, F. C. Nielsen, and A. H. Lund, "MicroRNA-10a binds the $5^{\prime}$ UTR of ribosomal protein mRNAs and enhances their translation," Molecular Cell, vol. 30, no. 4, pp. 460-471, 2008.

[7] I. Rigoutsos, "New tricks for animal micrornas: targeting of amino acid coding regions at conserved and nonconserved sites," Cancer Research, vol. 69, no. 8, pp. 3245-3248, 2009.

[8] V. N. Kim, J. Han, and M. C. Siomi, "Biogenesis of small RNAs in animals," Nature Reviews Molecular Cell Biology, vol. 10, no. 2, pp. 126-139, 2009.

[9] X. Cai, C. H. Hagedorn, and B. R. Cullen, "Human microRNAs are processed from capped, polyadenylated transcripts that can also function as mRNAs," RNA, vol. 10, no. 12, pp. 1957-1966, 2004.

[10] R. I. Gregory, K. P. Yan, G. Amuthan et al., “The Microprocessor complex mediates the genesis of microRNAs," Nature, vol. 432, no. 7014, pp. 235-240, 2004.

[11] C. Okada, E. Yamashita, S. J. Lee et al., "A high-Resolution structure of the pre-microrna nuclear export machinery," Science, vol. 326, no. 5957, pp. 1275-1279, 2009.

[12] T. P. Chendrimada, R. I. Gregory, E. Kumaraswamy et al., "TRBP recruits the Dicer complex to Ago2 for microRNA processing and gene silencing," Nature, vol. 436, no. 7051, pp. 740-744, 2005.

[13] Y. Kim and V. N. Kim, "MicroRNA factory: RISC assembly from precursor microRNAs," Molecular Cell, vol. 46, pp. 384-386, 2012. 
[14] K. Okamura, J. W. Hagen, H. Duan, D. M. Tyler, and E. C. Lai, "The mirtron pathway generates microRNA-class regulatory RNAs in Drosophila," Cell, vol. 130, no. 1, pp. 89-100, 2007.

[15] C. Ender, A. Krek, M. R. Friedländer et al., "A human snoRNA with microRNA-like functions," Molecular Cell, vol. 32, no. 4, pp. 519-528, 2008.

[16] C. Cole, A. Sobala, C. Lu et al., "Filtering of deep sequencing data reveals the existence of abundant Dicer-dependent small RNAs derived from tRNAs," RNA, vol. 15, no. 12, pp. 2147-2160, 2009.

[17] J. E. Babiarz, J. G. Ruby, Y. Wang, D. P. Bartel, and R. Blelloch, "Mouse ES cells express endogenous shRNAs, siRNAs, and other microprocessor-independent, dicer-dependent small RNAs," Genes and Development, vol. 22, no. 20, pp. 2773-2785, 2008.

[18] D. L. Corcoran, K. V. Pandit, B. Gordon, A. Bhattacharjee, N. Kaminski, and P. V. Benos, "Features of mammalian microRNA promoters emerge from polymerase II chromatin immunoprecipitation data," PLoS ONE, vol. 4, no. 4, Article ID e5279, 2009.

[19] P. K. Rao, R. M. Kumar, M. Farkhondeh, S. Baskerville, and H. F. Lodish, "Myogenic factors that regulate expression of musclespecific microRNAs," Proceedings of the National Academy of Sciences of the United States of America, vol. 103, no. 23, pp. 87218726, 2006.

[20] K. A. O’Donnell, E. A. Wentzel, K. I. Zeller, C. V. Dang, and J. T. Mendell, "c-Myc-regulated microRNAs modulate E2F1 expression," Nature, vol. 435, no. 7043, pp. 839-843, 2005.

[21] N. H. Kim, H. S. Kim, N. G. Kim et al., "p53 and microRNA-34 are suppressors of canonical Wnt signaling," Science Signaling, vol. 4, p. ra71, 2011.

[22] F. M. Sanchez-Simon, X. X. Zhang, H. H. Loh, P. Y. Law, and R. E. Rodriguez, "Morphine regulates dopaminergic neuron differentiation via miR-133b," Molecular Pharmacology, vol. 78, no. 5, pp. 935-942, 2010.

[23] C. P. Bracken, P. A. Gregory, N. Kolesnikoff et al., "A doublenegative feedback loop between ZEB1-SIP1 and the microRNA200 family regulates epithelial-mesenchymal transition," Cancer Research, vol. 68, no. 19, pp. 7846-7854, 2008.

[24] Y. Saito, G. Liang, G. Egger et al., "Specific activation of microRNA-127 with downregulation of the proto-oncogene BCL6 by chromatin-modifying drugs in human cancer cells," Cancer Cell, vol. 9, no. 6, pp. 435-443, 2006.

[25] G. K. Scott, M. D. Mattie, C. E. Berger, S. C. Benz, and C. C. Benz, "Rapid alteration of microRNA levels by histone deacetylase inhibition," Cancer Research, vol. 66, no. 3, pp. 12771281, 2006.

[26] D. Sampath, C. Liu, K. Vasan et al., "Histone deacetylases mediate the silencing of miR-15a, miR-16, and miR-29b in chronic lymphocytic leukemia," Blood, vol. 119, pp. 1162-1172, 2012.

[27] J. M. Thomson, M. Newman, J. S. Parker, E. M. Morin-Kensicki, T. Wright, and S. M. Hammond, "Extensive post-transcriptional regulation of microRNAs and its implications for cancer," Genes and Development, vol. 20, no. 16, pp. 2202-2207, 2006.

[28] J. Mineno, S. Okamoto, T. Ando et al., "The expression profile of microRNAs in mouse embryos," Nucleic Acids Research, vol. 34, no. 6, pp. 1765-1771, 2006.

[29] D. R. Warner, V. Bhattacherjee, X. Yin et al., "Functional interaction between Smad, CREB binding protein, and p68 RNA helicase," Biochemical and Biophysical Research Communications, vol. 324, no. 1, pp. 70-76, 2004.
[30] H. I. Suzuki, K. Yamagata, K. Sugimoto, T. Iwamoto, S. Kato, and K. Miyazono, "Modulation of microRNA processing by $\mathrm{p} 53$," Nature, vol. 460, no. 7254, pp. 529-533, 2009.

[31] K. Yamagata, S. Fujiyama, S. Ito et al., "Maturation of microRNA is hormonally regulated by a nuclear receptor," Molecular Cell, vol. 36, no. 2, pp. 340-347, 2009.

[32] N. J. Lehrbach, J. Armisen, H. L. Lightfoot et al., "LIN-28 and the poly(U) polymerase PUP-2 regulate let-7 microRNA processing in Caenorhabditis elegans," Nature Structural and Molecular Biology, vol. 16, no. 10, pp. 1016-1020, 2009.

[33] N. J. Martinez and R. I. Gregory, "MicroRNA gene regulatory pathways in the establishment and maintenance of ESC identity," Cell stem cell, vol. 7, no. 1, pp. 31-35, 2010.

[34] A. Rybak, H. Fuchs, L. Smirnova et al., "A feedback loop comprising lin-28 and let-7 controls pre-let-7 maturation during neural stem-cell commitment," Nature Cell Biology, vol. 10, no. 8, pp. 987-993, 2008.

[35] H. B. El-Serag, "Epidemiology of viral hepatitis and hepatocellular carcinoma," Gastroenterology, vol. 142, pp. 1264-1273, 2012.

[36] W. H. Liu, S. H. Yeh, and P. J. Chen, "Role of microRNAs in hepatitis B virus replication and pathogenesis," Biochim Biophys Acta, vol. 1809, pp. 678-685, 2011.

[37] B. Wang, S. Majumder, G. Nuovo et al., "Role of microRNA155 at early stages of hepatocarcinogenesis induced by cholinedeficient and amino acid-defined diet in C57BL/6 mice," Нераtology, vol. 50, no. 4, pp. 1152-1161, 2009.

[38] W. H. Liu, S. H. Yeh, C. C. Lu et al., "MicroRNA-18a prevents estrogen receptor- $\alpha$ expression, promoting proliferation of hepatocellular carcinoma cells," Gastroenterology, vol. 136, no. 2, pp. 683-693, 2009.

[39] Y. Saito, Y. Kanai, T. Nakagawa et al., "Increased protein expression of DNA methyltransferase (DNMT) 1 is significantly correlated with the malignant potential and poor prognosis of human hepatocellular carcinomas," International Journal of Cancer, vol. 105, no. 4, pp. 527-532, 2003.

[40] X. Zhang, E. Zhang, Z. Ma et al., "Modulation of hepatitis B virus replication and hepatocyte differentiation by MicroRNA1," Hepatology, vol. 53, no. 5, pp. 1476-1485, 2011.

[41] Y. Wang, Y. Lu, S. T. Toh et al., "Lethal-7 is down-regulated by the hepatitis B virus $\mathrm{x}$ protein and targets signal transducer and activator of transcription 3," Journal of Hepatology, vol. 53, no. 1, pp. 57-66, 2010.

[42] Z. Wang, S. Lin, J. J. Li et al., "MYC protein inhibits transcription of the microRNA cluster MC-let-7a-1 let-7d via noncanonical E-box," The Journal of Biological Chemistry, vol. 286, no. 46, pp. 39703-39714, 2011.

[43] S. L. Au, C. C. Wong, J. M. Lee et al., "Enhancer of zeste homolog 2 epigenetically silences multiple tumor suppressor microRNAs to promote liver cancer metastasis," Hepatology, vol. 56, pp. 622631, 2012.

[44] S. M. Johnson, H. Grosshans, J. Shingara et al., "RAS is regulated by the let-7 microRNA family," Cell, vol. 120, no. 5, pp. 635-647, 2005.

[45] C. Mayr, M. T. Hemann, and D. P. Bartel, "Disrupting the pairing between let-7 and Hmga 2 enhances oncogenic transformation," Science, vol. 315, no. 5818, pp. 1576-1579, 2007.

[46] V. B. Sampson, N. H. Rong, J. Han et al., "MicroRNA let7a down-regulates MYC and reverts MYC-induced growth in Burkitt lymphoma cells," Cancer Research, vol. 67, no. 20, pp. 9762-9770, 2007. 
[47] W. Hou, Q. Tian, J. Zheng, and H. L. Bonkovsky, "MicroRNA196 represses Bachl protein and hepatitis $C$ virus gene expression in human hepatoma cells expressing hepatitis $C$ viral proteins," Hepatology, vol. 51, no. 5, pp. 1494-1504, 2010.

[48] H. Yin, M. Hu, R. Zhang, Z. Shen, L. Flatow, and M. You, "MicroRNA-217 promotes ethanol-induced fat accumulation in hepatocytes by down-regulating SIRT1," The Journal of Biological Chemistry, vol. 287, no. 13, pp. 9817-9826, 2012.

[49] Y. Ladeiro, G. Couchy, C. Balabaud et al., "MicroRNA profiling in hepatocellular tumors is associated with clinical features and oncogene/tumor suppressor gene mutations," Hepatology, vol. 47, no. 6, pp. 1955-1963, 2008.

[50] A. Dolganiuc, J. Petrasek, K. Kodys et al., "MicroRNA expression profile in lieber-decarli diet-induced alcoholic and methionine choline deficient diet-induced nonalcoholic steatohepatitis models in mice," Alcoholism: Clinical and Experimental Research, vol. 33, no. 10, pp. 1704-1710, 2009.

[51] M. Vinciguerra, A. Sgroi, C. Veyrat-Durebex, L. Rubbia-Brandt, L. H. Buhler, and M. Foti, "Unsaturated fatty acids inhibit the expression of tumor suppressor phosphatase and tensin homolog(PTEN) via microRNA-21 up-regulation in hepatocytes," Hepatology, vol. 49, no. 4, pp. 1176-1184, 2009.

[52] R. M. O'Connell, D. S. Rao, A. A. Chaudhuri et al., "Sustained expression of microRNA-155 in hematopoietic stem cells causes a myeloproliferative disorder," Journal of Experimental Medicine, vol. 205, no. 3, pp. 585-594, 2008.

[53] L. Xu, W. Qin, H. Zhang et al., "Alterations in microRNA expression linked to microcystin-LR-induced tumorigenicity in human WRL-68 Cells," Mutation Research, vol. 743, pp. 75-82, 2012.

[54] Y. Zhao, P. Xie, and H. Fan, "Genomic profiling of microRNAs and proteomics reveals an early molecular alteration associated with tumorigenesis induced by MC-LR in mice," Environmental Science \& Technology, vol. 46, pp. 34-41, 2012.

[55] E. Elyakim, E. Sitbon, A. Faerman et al., "hsa-miR-191 is a candidate oncogene target for hepatocellular carcinoma therapy," Cancer Research, vol. 70, no. 20, pp. 8077-8087, 2010.

[56] D. Hanahan and R. A. Weinberg, "Hallmarks of cancer: the next generation,” Cell, vol. 144, no. 5, pp. 646-674, 2011.

[57] T. Xu, Y. Zhu, Y. Xiong, Y. Y. Ge, J. P. Yun, and S. M. Zhuang, "MicroRNA-195 suppresses tumorigenicity and regulates G1/S transition of human hepatocellular carcinoma cells," Hepatology, vol. 50, no. 1, pp. 113-121, 2009.

[58] J. Kota, R. R. Chivukula, K. A. O’Donnell et al., “Therapeutic microRNA delivery suppresses tumorigenesis in a murine liver cancer model," Cell, vol. 137, no. 6, pp. 1005-1017, 2009.

[59] Y. Li, W. Tan, T. W. L. Neo et al., "Role of the miR-106b-25 microRNA cluster in hepatocellular carcinoma," Cancer Science, vol. 100, no. 7, pp. 1234-1242, 2009.

[60] J. Cheng, L. Zhou, Q. F. Xie et al., "The impact of miR-34a on protein output in hepatocellular carcinoma HepG2 cells," Proteomics, vol. 10, no. 8, pp. 1557-1572, 2010.

[61] Q. W. L. Wong, R. W. M. Lung, P. T. Y. Law et al., "MicroRNA223 is commonly repressed in hepatocellular carcinoma and potentiates expression of Stathminl," Gastroenterology, vol. 135, no. 1, pp. 257-269, 2008.

[62] C. Xu, S. Liu, H. Fu et al., "MicroRNA-193b regulates proliferation, migration and invasion in human hepatocellular carcinoma cells," European Journal of Cancer, vol. 46, no. 15, pp. 2828-2836, 2010.
[63] W. Zhang, G. Kong, J. Zhang, T. Wang, L. Ye, and X. Zhang, "MicroRNA-520b inhibits growth of hepatoma cells by targeting MEKK2 and cyclin D1," PLoS ONE, vol. 7, Article ID e31450, 2012.

[64] L. Gramantieri, F. Fornari, M. Ferracin et al., "MicroRNA-221 targets Bmf in hepatocellular carcinoma and correlates with tumor multifocality," Clinical Cancer Research, vol. 15, no. 16, pp. 5073-5081, 2009.

[65] A. D. Sharma, N. Narain, E. M. Händel et al., "MicroRNA-221 regulates FAS-induced fulminant liver failure," Hepatology, vol. 53, no. 5, pp. 1651-1661, 2011.

[66] A. Zhao, Q. Zeng, X. Xie et al., "MicroRNA-125b induces cancer cell apoptosis through suppression of Bcl-2 expression," Journal of Genetics and Genomics, vol. 39, pp. 29-35, 2012.

[67] J. Gong, J. P. Zhang, B. Li et al., "MicroRNA-125b promotes apoptosis by regulating the expression of Mcl-1, Bcl-w and IL6R," Oncogene, 2012.

[68] Y. Zhang, S. Takahashi, A. Tasaka, T. Yoshima, H. Ochi, and K. Chayama, "Involvement of microRNA-224 in cell proliferation, migration, invasion and anti-apoptosis in hepatocellular carcinoma," Journal of Gastroenterology and Hepatology, 2012.

[69] Y. Xiong, J. H. Fang, J. P. Yun et al., "Effects of microrna-29 on apoptosis, tumorigenicity, and prognosis of hepatocellular carcinoma," Hepatology, vol. 51, no. 3, pp. 836-845, 2010.

[70] H. Su, J. R. Yang, T. Xu et al., "MicroRNA-101, down-regulated in hepatocellular carcinoma, promotes apoptosis and suppresses tumorigenicity," Cancer Research, vol. 69, no. 3, pp. 1135-1142, 2009.

[71] C. J. F. Lin, H. Y. Gong, H. C. Tseng, W. L. Wang, and J. L. Wu, "miR-122 targets an anti-apoptotic gene, Bcl-w, in human hepatocellular carcinoma cell lines," Biochemical and Biophysical Research Communications, vol. 375, no. 3, pp. 315320, 2008.

[72] M. Garofalo, G. Di Leva, G. Romano et al., "miR-221\&222 regulate TRAIL resistance and enhance tumorigenicity through PTEN and TIMP3 downregulation," Cancer Cell, vol. 16, no. 6, pp. 498-509, 2009.

[73] S. Shimizu, T. Takehara, H. Hikita et al., "The let-7 family of microRNAs inhibits Bcl-xL expression and potentiates sorafenib-induced apoptosis in human hepatocellular carcinoma," Journal of Hepatology, vol. 52, no. 5, pp. 698-704, 2010.

[74] K. Wu, J. Ding, C. Chen et al., "Hepatic transforming growth factor beta gives rise to tumor-initiating cells and promotes liver cancer development," Hepatology, vol. 56, pp. 2255-2267, 2012.

[75] F. Meng, R. Henson, H. Wehbe-Janek, K. Ghoshal, S. T. Jacob, and T. Patel, "MicroRNA-21 regulates expression of the PTEN tumor suppressor gene in human hepatocellular cancer," Gastroenterology, vol. 133, no. 2, pp. 647-658, 2007.

[76] K. Yuan, Z. Lian, B. Sun, M. M. Clayton, I. O. Ng, and M. A. Feitelson, "Role of miR-148a in hepatitis B associated hepatocellular carcinoma," PLoS ONE, vol. 7, no. 4, Article ID e35331, 2012.

[77] F. Fornari, M. Milazzo, P. Chieco et al., "In hepatocellular carcinoma miR-519d is up-regulated by p53 and DNA hypomethylation and targets CDKN1A/p21, PTEN, AKT3 and TIMP2," The Journal of Pathology, vol. 227, pp. 275-285, 2012.

[78] G. Kong, J. Zhang, S. Zhang, C. Shan, L. Ye, and X. Zhang, "Upregulated microRNA-29a by hepatitis B virus X protein enhances hepatoma cell migration by targeting PTEN in cell culture model," PLoS ONE, vol. 6, no. 5, Article ID e19518, 2011. 
[79] Y. Fang, J. L. Xue, Q. Shen, J. Chen, and L. Tian, "MicroRNA-7 inhibits tumor growth and metastasis by targeting the phosphoinositide 3-kinase/Akt pathway in hepatocellular carcinoma," Hepatology, vol. 55, pp. 1852-1862, 2012.

[80] F. Fornari, M. Milazzo, P. Chieco et al., "MiR-199a-3p regulates mTOR and c-Met to influence the doxorubicin sensitivity of human hepatocarcinoma cells," Cancer Research, vol. 70, no. 12, pp. 5184-5193, 2010.

[81] A. Salvi, C. Sabelli, S. Moncini et al., "MicroRNA-23b mediates urokinase and c-met downmodulation and a decreased migration of human hepatocellular carcinoma cells," FEBS Journal, vol. 276, no. 11, pp. 2966-2982, 2009.

[82] J. Datta, H. Kutay, M. W. Nasser et al., "Methylation mediated silencing of microRNA-1 gene and its role in hepatocellular carcinogenesis," Cancer Research, vol. 68, no. 13, pp. 5049-5058, 2008.

[83] S. Tan, R. Li, K. Ding, P. E. Lobie, and T. Zhu, "MiR-198 inhibits migration and invasion of hepatocellular carcinoma cells by targeting the HGF/c-MET pathway," FEBS Letters, vol. 585, no. 14, pp. 2229-2234, 2011.

[84] R. Buurman, E. Gurlevik, V. Schaffer et al., "Histone deacetylases activate hepatocyte growth factor signaling by repressing microRNA-449 in hepatocellular carcinoma cells," Gastroenterology, vol. 143, pp. 811-820, 2012.

[85] N. Li, H. Fu, Y. Tie et al., "miR-34a inhibits migration and invasion by down-regulation of c-Met expression in human hepatocellular carcinoma cells," Cancer Letters, vol. 275, no. 1, pp. 44-53, 2009.

[86] P. K. Santhekadur, S. K. Das, R. Gredler et al., "Multifunction protein staphylococcal nuclease domain containing 1 (SND1) promotes tumor angiogenesis in human hepatocellular carcinoma through novel pathway that involves nuclear factor $\kappa \mathrm{B}$ and miR-221," The Journal of Biological Chemistry, vol. 287, no. 17, pp. 13952-13958, 2012.

[87] T. C. Shih, Y. J. Tien, C. J. Wen et al., "MicroRNA-214 downregulation contributes to tumor angiogenesis by inducing secretion of the hepatoma-derived growth factor in human hepatoma," Journal of Hepatology, vol. 57, no. 3, pp. 584-591, 2012.

[88] W. C. Tsai, P. W. C. Hsu, T. C. Lai et al., "MicroRNA-122, a tumor suppressor MicroRNA that regulates intrahepatic metastasis of hepatocellular carcinoma," Hepatology, vol. 49, no. 5, pp. 1571$1582,2009$.

[89] J. H. Fang, H. C. Zhou, C. Zeng et al., "MicroRNA-29b suppresses tumor angiogenesis, invasion, and metastasis by regulating matrix metalloproteinase 2 expression," Hepatology, vol. 54, pp. 1729-1740, 2011.

[90] G. Alpini, S. S. Glaser, J. P. Zhang et al., "Regulation of placenta growth factor by microRNA-125b in hepatocellular cancer," Journal of Hepatology, vol. 55, pp. 1339-1345, 2011.

[91] W. P. Tsang and T. T. Kwok, "Let-7a microRNA suppresses therapeutics-induced cancer cell death by targeting caspase-3," Apoptosis, vol. 13, no. 10, pp. 1215-1222, 2008.

[92] P. Di Fazio, R. Montalbano, D. Neureiter et al., "Downregulation of HMGA2 by the pan-deacetylase inhibitor panobinostat is dependent on hsa-let-7b expression in liver cancer cell lines," Experimental Cell Research, vol. 318, pp. 1832-1843, 2012.

[93] X. M. Zhu, L. J. Wu, J. Xu, R. Yang, and F. S. Wu, "Let-7c microRNA expression and clinical significance in hepatocellular carcinoma," The Journal of International Medical Research, vol. 39, pp. 2323-2329, 2011.

[94] Y. M. Shah, K. Morimura, Q. Yang, T. Tanabe, M. Takagi, and F. J. Gonzalez, "Peroxisome proliferator-activated receptor $\alpha$ regulates a microRNA-mediated signaling cascade responsible for hepatocellular proliferation," Molecular and Cellular Biology, vol. 27, no. 12, pp. 4238-4247, 2007.

[95] J. Ji, L. Zhao, A. Budhu et al., "Let-7g targets collagen type I $\alpha 2$ and inhibits cell migration in hepatocellular carcinoma," Journal of Hepatology, vol. 52, no. 5, pp. 690-697, 2010.

[96] F. F. Lan, H. Wang, Y. C. Chen et al., "Hsa-let-7g inhibits proliferation of hepatocellular carcinoma cells by downregulation of c-Myc and upregulation of p16INK4A," International Journal of Cancer, vol. 128, no. 2, pp. 319-331, 2011.

[97] D. Li, P. Yang, H. Li et al., "MicroRNA-1 inhibits proliferation of hepatocarcinoma cells by targeting endothelin-1," Life Sciences, vol. 91, pp. 440-447, 2012.

[98] X. Wei, T. Xiang, G. Ren et al., "miR-101 is down-regulated by the hepatitis $\mathrm{B}$ virus $\mathrm{x}$ protein and induces aberrant DNA methylation by targeting DNA methyltransferase 3A," Cell Signal, vol. 25, pp. 439-446, 2012.

[99] Y. Zhang, X. Guo, L. Xiong et al., "MicroRNA-101 suppresses SOX9-dependent tumorigenicity and promotes favorable prognosis of human hepatocellular carcinoma," FEBS Letters, vol. 586, no. 24, pp. 4362-4370, 2012.

[100] H. V. Reddi, P. Madde, D. Milosevic et al., "The putative PAX8/PPAR $\gamma$ fusion oncoprotein exhibits partial tumor suppressor activity through up-regulation of Micro-RNA-122 and dominant-negative PPAR $\gamma$ activity," Genes and Cancer, vol. 2, no. 1, pp. 46-55, 2011.

[101] J. Xu, X. Zhu, L. Wu et al., "MicroRNA-122 suppresses cell proliferation and induces cell apoptosis in hepatocellular carcinoma by directly targeting Wnt/ $\beta$-catenin pathway," Liver International, vol. 32, no. 5, pp. 752-760, 2012.

[102] Q. Lang and C. Ling, "MiR-124 suppresses cell proliferation in hepatocellular carcinoma by targeting PIK3CA," Biochemical and Biophysical Research Communications, vol. 426, pp. 247252, 2012.

[103] Q. Bi, S. Tang, L. Xia et al., "Ectopic expression of MiR$125 \mathrm{a}$ inhibits the proliferation and metastasis of hepatocellular carcinoma by targeting MMP11 and VEGF," PLoS ONE, vol. 7, no. 6, Article ID e40169, 2012.

[104] J. K. Kim, J. H. Noh, K. H. Jung et al., "SIRT7 oncogenic potential in human hepatocellular carcinoma and its regulation by the tumor suppressors mir-125a-5p and mir-125b," Hepatology, 2012.

[105] L. Liang, C. M. Wong, Q. Ying et al., "MicroRNA-125b suppressesed human liver cancer cell proliferation and metastasis by directly targeting oncogene LIN28B2," Hepatology, vol. 52, no. 5, pp. 1731-1740, 2010.

[106] D. N. Fan, F. H. Tsang, A. H. Tam et al., "Histone lysine methyltransferase, suppressor of variegation 3-9 homolog 1, promotes hepatocellular carcinoma progression and is negatively regulated by microRNA-125b," Hepatology, 2012.

[107] C. C. Wong, C. Wong, E. K. Tung et al., “The MicroRNA miR139 suppresses metastasis and progression of hepatocellular carcinoma by down-regulating rho-kinase 2," Gastroenterology, vol. 140, no. 1, pp. 322-331, 2011.

[108] Q. Fan, M. He, X. Deng et al., "Derepression of c-Fos caused by MicroRNA-139 down-regulation contributes to the metastasis of human hepatocellular carcinoma," Cell Biochemistry and Function, 2012.

[109] W. Wang, L. J. Zhao, Y. X. Tan, H. Ren, and Z. T. Qi, “MiR-138 induces cell cycle arrest by targeting cyclin D3 in hepatocellular carcinoma," Carcinogenesis, vol. 33, pp. 1113-1120, 2012. 
[110] P. T. Law, A. K. Ching, A. W. Chan et al., "MiR-145 modulates multiple components of the insulin-like growth factor pathway in hepatocellular carcinoma," Carcinogenesis, vol. 33, pp. 1134$1141,2012$.

[111] Y. Jia, H. Liu, Q. Zhuang et al., “Tumorigenicity of cancer stem-like cells derived from hepatocarcinoma is regulated by microRNA-145," Oncology Reports, vol. 27, pp. 1865-1872, 2012.

[112] X. Yang, J. Yu, J. Yin, Q. Xiang, H. Tang, and X. Lei, “MiR-195 regulates cell apoptosis of human hepatocellular carcinoma cells by targeting LATS2," Pharmazie, vol. 67, pp. 645-651, 2012.

[113] J. Hou, L. Lin, W. Zhou et al., "Identification of miRNomes in human liver and hepatocellular carcinoma reveals miR-199a/b$3 \mathrm{p}$ as therapeutic target for hepatocellular carcinoma," Cancer Cell, vol. 19, no. 2, pp. 232-243, 2011.

[114] T. Shatseva, D. Y. Lee, Z. Deng, and B. B. Yang, "MicroRNA miR$199 \mathrm{a}-3 \mathrm{p}$ regulates cell proliferation and survival by targeting caveolin-2," Journal of Cell Science, vol. 124, no. 16, pp. 28262836, 2011.

[115] Q. Shen, V. R. Cicinnati, X. Zhang et al., "Role of microRNA199a-5p and discoidin domain receptor 1 in human hepatocellular carcinoma invasion," Molecular Cancer, vol. 9, article 227, 2010.

[116] N. Xu, J. Zhang, C. Shen et al., "Cisplatin-induced downregulation of miR-199a-5p increases drug resistance by activating autophagy in HCC cell," Biochemical and Biophysical Research Communications, vol. 423, pp. 826-831, 2012.

[117] J. H. Yuan, F. Yang, B. F. Chen et al., "The histone deacetylase 4/SP1/microrna-200a regulatory network contributes to aberrant histone acetylation in hepatocellular carcinoma," Hepatology, vol. 54, pp. 2025-2035, 2011.

[118] W. Wei, L. Wanjun, S. Hui, C. Dongyue, Y. Xinjun, and Z. Jisheng, "miR-203 inhibits proliferation of HCC cells by targeting survivin," Cell Biochemistry and Function, vol. 31, no. 1, pp. 82-85, 2012.

[119] X. Wang, J. Chen, F. Li et al., "MiR-214 inhibits cell growth in hepatocellular carcinoma through suppression of $\beta$-catenin," Biochemical and Biophysical Research Communications, vol. 428, no. 4, pp. 525-531, 2012.

[120] H. Xia, L. L. Ooi, and K. M. Hui, "MiR-214 targets $\beta$-catenin pathway to suppress invasion, stem-like traits and recurrence of human hepatocellular carcinoma," PLoS ONE, vol. 7, no. 9, Article ID e44206, 2012.

[121] N. Huang, J. Lin, J. Ruan et al., "MiR-219-5p inhibits hepatocellular carcinoma cell proliferation by targeting glypican-3," FEBS Letters, vol. 586, pp. 884-891, 2012.

[122] Y. Zhu, Y. Lu, Q. Zhang et al., "MicroRNA-26a/b and their host genes cooperate to inhibit the G1/S transition by activating the pRb protein," Nucleic Acids Research, vol. 40, pp. 4615-4625, 2012.

[123] X. C. Zhu, Q. Z. Dong, X. F. Zhang et al., "microRNA-29a suppresses cell proliferation by targeting SPARC in hepatocellular carcinoma," International Journal of Molecular Medicine, vol. 30, no. 6, pp. 1321-1326, 2012.

[124] P. Yang, Q. J. Li, Y. Feng et al., “TGF- $\beta$-miR-34a-CCL22 signaling-induced Treg cell recruitment promotes venous metastases of HBV-positive hepatocellular carcinoma," Cancer Cell, vol. 22, pp. 291-303, 2012.

[125] Y. Chang, W. Yan, X. He et al., "miR-375 inhibits autophagy and reduces viability of hepatocellular carcinoma cells under hypoxic conditions," Gastroenterology, vol. 143, pp. 177-187, 2012.
[126] Y. Zheng, L. Yin, H. Chen et al., "miR-376a suppresses proliferation and induces apoptosis in hepatocellular carcinoma," FEBS Letters, vol. 586, pp. 2396-2403, 2012.

[127] Z. Weng, D. Wang, W. Zhao et al., "microRNA-450a targets DNA methyltransferase 3a in hepatocellular carcinoma," Experimental and Therapeutic Medicine, vol. 2, no. 5, pp. 951-955, 2011.

[128] Y. Yan, Y. C. Luo, H. Y. Wan et al., "MicroRNA-10a is involved in the metastatic process by regulating Eph tyrosine kinase receptor A4-Mediated epithelial-mesenchymal transition and adhesion in hepatoma cells," Hepatology, 2012.

[129] Q. J. Li, L. Zhou, F. Yang et al., "MicroRNA-10b promotes migration and invasion through CADM1 in human hepatocellular carcinoma cells," Tumour Biology, vol. 33, no. 5, pp. 1455-1465, 2012.

[130] N. Xu, C. Shen, Y. Luo et al., "Upregulated miR-130a increases drug resistance by regulating RUNX3 and Wnt signaling in cisplatin-treated HCC cell," Biochemical and Biophysical Research Communications, vol. 425, pp. 468-472, 2012.

[131] S. Liu, W. Guo, J. Shi et al., "MicroRNA-135a contributes to the development of portal vein tumor thrombus by promoting metastasis in hepatocellular carcinoma," Journal of Hepatology, vol. 56, pp. 389-396, 2012.

[132] X. Zhang, S. Liu, T. Hu, S. Liu, Y. He, and S. Sun, "Upregulated microRNA-143 transcribed by nuclear factor kappa B enhances hepatocarcinoma metastasis by repressing fibronectin expression," Hepatology, vol. 50, no. 2, pp. 490-499, 2009.

[133] Y. Zhang, W. Wei, N. Cheng et al., "Hepatitis C virus-induced up-regulation of microRNA-155 promotes hepatocarcinogenesis by activating Wnt signaling," Hepatology, vol. 56, pp. 16311640, 2012.

[134] B. Wang, S. H. Hsu, S. Majumder et al., “TGF $\beta$-mediated upregulation of hepatic miR-181b promotes hepatocarcinogenesis by targeting TIMP3," Oncogene, vol. 29, no. 12, pp. 1787-1797, 2010.

[135] J. Wang, J. Li, J. Shen, C. Wang, L. Yang, and X. Zhang, "MicroRNA-182 downregulates metastasis suppressor 1 and contributes to metastasis of hepatocellular carcinoma," BMC Cancer, vol. 12, p. 227, 2012.

[136] Y. Tomimaru, H. Eguchi, H. Nagano et al., "MicroRNA-21 induces resistance to the anti-tumour effect of interferon- $\alpha / 5$ fluorouracil in hepatocellular carcinoma cells," British Journal of Cancer, vol. 103, no. 10, pp. 1617-1626, 2010.

[137] E. C. Connolly, K. Van Doorslaer, L. E. Rogler, and C. E. Rogler, "Overexpression of miR-21 promotes an in vitro metastatic phenotype by targeting the tumor suppressor RHOB," Molecular Cancer Research, vol. 8, no. 5, pp. 691-700, 2010.

[138] Q. Zhu, Z. Wang, Y. Hu et al., "miR-21 promotes migration and invasion by the miR-21-PDCD4-AP-1 feedback loop in human hepatocellular carcinoma," Oncology Reports, vol. 27, pp. 1660$1668,2012$.

[139] Q. Ying, L. Liang, W. Guo et al., "Hypoxia-inducible microRNA210 augments the metastatic potential of tumor cells by targeting vacuole membrane protein 1 in hepatocellular carcinoma," Hepatology, vol. 54, pp. 2064-2075, 2011.

[140] W. Yang, T. Sun, J. Cao, F. Liu, Y. Tian, and W. Zhu, "Downregulation of miR-210 expression inhibits proliferation, induces apoptosis and enhances radiosensitivity in hypoxic human hepatoma cells in vitro," Experimental Cell Research, vol. 318, pp. 944-954, 2012.

[141] P. J. Chen, S. H. Yeh, W. H. Liu et al., "Androgen pathway stimulates microRNA-216a transcription to suppress the tumor suppressor in lung cancer-1 gene in early hepatocarcinogenesis," Hepatology, vol. 56, pp. 632-643, 2012. 
[142] F. Fornari, L. Gramantieri, M. Ferracin et al., "MiR-221 controls CDKN1C/p57 and CDKN1B/p27 expression in human hepatocellular carcinoma," Oncogene, vol. 27, no. 43, pp. 5651-5661, 2008.

[143] P. Pineau, S. Volinia, K. McJunkin et al., "miR-221 overexpression contributes to liver tumorigenesis," Proceedings of the National Academy of Sciences of the United States of America, vol. 107, no. 1, pp. 264-269, 2010.

[144] Q. Yuan, K. Loya, B. Rani et al., "MicroRNA-221 overexpression accelerates hepatocyte proliferation during liver regeneration," Hepatology, vol. 57, no. 1, pp. 299-310, 2012.

[145] M. Notarbartolo, L. Giannitrapani, N. Vivona et al., "Frequent alteration of the Yin Yang 1/Raf-1 Kinase inhibitory protein ratio in hepatocellular carcinoma," OMICS A Journal of Integrative Biology, vol. 15, no. 5, pp. 267-272, 2011.

[146] Y. Wang, H. C. Toh, P. Chow et al., "MicroRNA-224 is up-regulated in hepatocellular carcinoma through epigenetic mechanisms," The FASEB Journal, vol. 26, pp. 3032-3041, 2012.

[147] C. Scisciani, S. Vossio, F. Guerrieri et al., "Transcriptional regulation of miR-224 upregulated in human HCCs by $\mathrm{NF} \kappa \mathrm{B}$ inflammatory pathways," Journal of Hepatology, vol. 56, no. 4, pp. 855-861, 2012.

[148] Y. Wang, A. T. C. Lee, J. Z. I. Ma et al., "Profiling microRNA expression in hepatocellular carcinoma reveals microRNA-224 up-regulation and apoptosis inhibitor-5 as a microRNA-224specific target," Journal of Biological Chemistry, vol. 283, no. 19, pp. 13205-13215, 2008.

[149] B. Wang, S. H. Hsu, W. Frankel, K. Ghoshal, and S. T. Jacob, "Stat3-mediated activation of microRNA-23a suppresses gluconeogenesis in hepatocellular carcinoma by down-regulating glucose-6-phosphatase and peroxisome proliferator-activated receptor gamma, coactivator 1 alpha," Hepatology, vol. 56, pp. 186-197, 2012.

[150] N. Wu, X. Liu, X. Xu et al., "MicroRNA-373, a new regulator of protein phosphatase 6 , functions as an oncogene in hepatocellular carcinoma," FEBS Journal, vol. 278, no. 12, pp. 2044-2054, 2011.

[151] P. Zhou, W. Jiang, L. Wu, R. Chang, K. Wu, and Z. Wang, "miR301a is a candidate oncogene that targets the homeobox gene Gax in human hepatocellular carcinoma," Digestive Diseases and Sciences, vol. 57, pp. 1171-1180, 2012.

[152] L. Y. Zhang, M. Liu, X. Li, and H. Tang, "MiR-490-3p modulates cell growth and epithelial to mesenchymal transition of hepatocellular carcinoma cells by targeting endoplasmic reticulumGolgi intermediate compartment protein $3^{*}$ (ERGIC3)," The Journal of Biological Chemistry, 2012.

[153] Q. Tian, L. Liang, J. Ding et al., "MicroRNA-550a acts as a prometastatic gene and directly targets cytoplasmic polyadenylation element-binding protein 4 in hepatocellular carcinoma," PLoS ONE, vol. 7, no. 11, Article ID e48958, 2012.

[154] X. Jiang, G. Xiang, Y. Wang et al., "MicroRNA-590-5p regulates proliferation and invasion in human hepatocellular carcinoma cells by targeting TGF- $\beta$ RII," Molecules and Cells, vol. 33, no. 6 , pp. 545-551, 2012.

[155] H. M. El Tayebi, K. A. Hosny, G. Esmat, K. Breuhahn, and A. I. Abdelaziz, "miR-615-5p is restrictedly expressed in cirrhotic and cancerous liver tissues and its overexpression alleviates the tumorigenic effects in hepatocellular carcinoma," FEBS Letters, vol. 586, pp. 3309-3316, 2012.

[156] L. Zhang, L. Yang, X. Liu et al., "MiR-657 promotes tumorigenesis in hepatocellular carcinoma by targeting transducin-like enhancer protein 1 through NF- $\kappa$ B pathways," Hepatology, 2012.
[157] M. S. Kwak, D. H. Lee, Y. Cho et al., "Association of polymorphism in pri-microRNAs-371-372-373 with the occurrence of hepatocellular carcinoma in hepatitis B virus infected patients," PLoS ONE, vol. 7, Article ID e41983, 2012.

[158] J. S. Bae, J. H. Kim, C. F. Pasaje et al., "Association study of genetic variations in microRNAs with the risk of hepatitis Brelated liver diseases," Digestive and Liver Disease, vol. 44, pp. 849-854, 2012.

[159] W. H. Kim, K. T. Min, Y. J. Jeon et al., "Association study of microRNA polymorphisms with hepatocellular carcinoma in Korean population," Gene, vol. 504, pp. 92-97, 2012.

[160] H. Akkiz, S. Bayram, A. Bekar, E. Akgollu, and O. Uskudar, "Genetic variation in the microRNA-499 gene and hepatocellular carcinoma risk in a Turkish population: lack of any association in a case-control study," Asian Pacific Journal of Cancer Prevention, vol. 12, pp. 3107-3112, 2011.

[161] Y. Xiang, S. Fan, J. Cao, S. Huang, and L. P. Zhang, "Association of the microRNA-499 variants with susceptibility to hepatocellular carcinoma in a Chinese population," Molecular Biology Reports, vol. 39, pp. 7019-7023, 2012.

[162] Y. Xu, L. Liu, J. Liu et al., "A potentially functional polymorphism in the promoter region of $\mathrm{miR}-34 \mathrm{~b} / \mathrm{c}$ is associated with an increased risk for primary hepatocellular carcinoma," International Journal of Cancer, vol. 128, no. 2, pp. 412-417, 2011.

[163] J. Guo, M. Jin, M. Zhang, and K. Chen, "A genetic variant in miR-196a2 increased digestive system cancer risks: a metaanalysis of 15 case-control studies," PLoS ONE, vol. 7, no. 1, Article ID e30585, 2012.

[164] X. D. Li, Z. G. Li, X. X. Song, and C. F. Liu, "A variant in microRNA-196a2 is associated with susceptibility to hepatocellular carcinoma in Chinese patients with cirrhosis," Pathology, vol. 42, no. 7, pp. 669-673, 2010.

[165] H. Akkaz, S. Bayram, A. Bekar, E. Akgöllü, and Y. Ülger, "A functional polymorphism in pre-microRNA-196a-2 contributes to the susceptibility of hepatocellular carcinoma in a Turkish population: a case-control study," Journal of Viral Hepatitis, vol. 18, no. 7, pp. e399-e407, 2011.

[166] H. Akkiz, S. Bayram, A. Bekar, E. Akgollu, O. Uskudar, and M. Sandikci, "No association of pre-microRNA-146a rs2910164 polymorphism and risk of hepatocellular carcinoma development in Turkish population: a case-control study," Gene, vol. 486, pp. 104-109, 2011.

[167] Y. Liu, Y. Zhang, J. Wen et al., "A genetic variant in the promoter region of miR-106b-25 cluster and risk of HBV infection and hepatocellular carcinoma," PLoS ONE, vol. 7, Article ID e32230, 2012.

[168] Y. Gao, Y. He, J. Ding et al., "An insertion/deletion polymorphism at miRNA-122-binding site in the interleukin-1a $3 \alpha$ untranslated region confers risk for hepatocellular carcinoma," Carcinogenesis, vol. 30, no. 12, pp. 2064-2069, 2009.

[169] S. Chen, Y. He, J. Ding et al., "An insertion/deletion polymorphism in the 31 untranslated region of $\beta$-transducin repeatcontaining protein $(\beta \operatorname{TrCP})$ is associated with susceptibility for hepatocellular carcinoma in Chinese," Biochemical and Biophysical Research Communications, vol. 391, no. 1, pp. 552556, 2010.

[170] C. Zhou, Q. Yu, L. Chen, J. Wang, S. Zheng, and J. Zhang, "A miR-1231 binding site polymorphism in the $3^{\prime}$ UTR of IFNAR 1 is associated with hepatocellular carcinoma susceptibility," Gene, vol. 507, pp. 95-98, 2012.

[171] Q. Yu, C. X. Zhou, N. S. Chen, S. D. Zheng, L. M. Shen, and J. K. Zhang, "A polymorphism within ErbB4 is associated with 
risk for hepatocellular carcinoma in Chinese population," World Journal of Gastroenterology, vol. 18, pp. 383-387, 2012.

[172] Z. Zhu, Y. Jiang, S. Chen et al., "An insertion/deletion polymorphism in the 3' untranslated region of type I collagen a2 (COL1A2) is associated with susceptibility for hepatocellular carcinoma in a Chinese population," Cancer Genetics, vol. 204, pp. 265-269, 2011.

[173] F. Zheng, Y. J. Liao, M. Y. Cai et al., “The putative tumour suppressor microRNA-124 modulates hepatocellular carcinoma cell aggressiveness by repressing ROCK2 and EZH2," Gut, vol. 61, pp. 278-289, 2012.

[174] T. Kim, A. Veronese, F. Pichiorri et al., "p53 regulates epithelialmesenchymal transition through microRNAs targeting ZEB1 and ZEB2," Journal of Experimental Medicine, vol. 208, no. 5, pp. 875-883, 2011.

[175] S. Toffanin, Y. Hoshida, A. Lachenmayer et al., "MicroRNAbased classification of hepatocellular carcinoma and oncogenic role of miR-517a," Gastroenterology, vol. 140, no. 5, pp. 16181628, 2011.

[176] Y. Murakami, T. Yasuda, K. Saigo et al., "Comprehensive analysis of microRNA expression patterns in hepatocellular carcinoma and non-tumorous tissues," Oncogene, vol. 25, no. 17, pp. 2537-2545, 2006.

[177] C. Augello, V. Vaira, L. Caruso et al., "MicroRNA profiling of hepatocarcinogenesis identifies C19MC cluster as a novel prognostic biomarker in hepatocellular carcinoma," Liver International, vol. 32, pp. 772-782, 2012.

[178] Q. W. L. Wong, A. K. K. Ching, A. W. H. Chan et al., "MiR-222 overexpression confers cell migratory advantages in hepatocellular carcinoma through enhancing AKT signaling," Clinical Cancer Research, vol. 16, no. 3, pp. 867-875, 2010.

[179] C. Coulouarn, V. M. Factor, J. B. Andersen, M. E. Durkin, and S. S. Thorgeirsson, "Loss of miR-122 expression in liver cancer correlates with suppression of the hepatic phenotype and gain of metastatic properties," Oncogene, vol. 28, no. 40, pp. 3526-3536, 2009.

[180] C. Wang, B. Song, W. Song et al., "Underexpressed microRNA199b-5p targets hypoxia-inducible factor- $1 \alpha$ in hepatocellular carcinoma and predicts prognosis of hepatocellular carcinoma patients," Journal of Gastroenterology and Hepatology, vol. 26, pp. 1630-1637, 2011.

[181] J. Zhang, Y. Yang, T. Yang et al., "MicroRNA-22, downregulated in hepatocellular carcinoma and correlated with prognosis, suppresses cell proliferation and tumourigenicity," British Journal of Cancer, vol. 103, no. 8, pp. 1215-1220, 2010.

[182] J. Ji, J. Shi, A. Budhu et al., "MicroRNA expression, survival, and response to interferon in liver cancer," The New England Journal of Medicine, vol. 361, pp. 1437-1447, 2009.

[183] D. Li, X. Liu, L. Lin et al., "MicroRNA-99a inhibits hepatocellular carcinoma growth and correlates with prognosis of patients with hepatocellular carcinoma," The Journal of Biological Chemistry, vol. 286, no. 42, pp. 36677-36685, 2011.

[184] W. Li, L. Xie, X. He et al., "Diagnostic and prognostic implications of microRNAs in human hepatocellular carcinoma," International Journal of Cancer, vol. 123, no. 7, pp. 1616-1622, 2008.

[185] L. Chen, M. Jiang, W. Yuan, and H. Tang, "miR-17-5p as a novel prognostic marker for hepatocellular carcinoma," Journal of Investigative Surgery, vol. 25, pp. 156-161, 2012.

[186] J. Zheng, P. Dong, S. Gao, N. Wang, and F. Yu, "High expression of serum miR-17-5p associated with poor prognosis in patients with hepatocellular carcinoma," Hepatogastroenterology, vol. 60, no. 123, 2012.

[187] Z. B. Han, H. Y. Chen, J. W. Fan, J. Y. Wu, H. M. Tang, and Z. H. Peng, "Up-regulation of microRNA-155 promotes cancer cell invasion and predicts poor survival of hepatocellular carcinoma following liver transplantation," Journal of Cancer Research and Clinical Oncology, vol. 138, pp. 153-161, 2012.

[188] A. Karakatsanis, I. Papaconstantinou, M. Gazouli, A. Lyberopoulou, G. Polymeneas, and D. Voros, "Expression of microRNAs, miR-21, miR-31, miR-122, miR-145, miR-146a, miR-200c, miR-221, miR-222, and miR-223 in patients with hepatocellular carcinoma or intrahepatic cholangiocarcinoma and its prognostic significance," Molecular Carcinogenesis, 2011.

[189] A. Budhu, H. L. Jia, M. Forgues et al., "Identification of metastasis-related microRNAs in hepatocellular carcinoma," Hepatology, vol. 47, no. 3, pp. 897-907, 2008.

[190] J. Jiang, Y. Gusev, I. Aderca et al., "Association of microRNA expression in hepatocellular carcinomas with hepatitis infection, cirrhosis, and patient survival," Clinical Cancer Research, vol. 14, no. 2, pp. 419-427, 2008.

[191] X. Chen, Y. Ba, L. Ma et al., "Characterization of microRNAs in serum: a novel class of biomarkers for diagnosis of cancer and other diseases," Cell Research, vol. 18, no. 10, pp. 997-1006, 2008.

[192] Y. Yamamoto, N. Kosaka, M. Tanaka et al., "MicroRNA-500 as a potential diagnostic marker for hepatocellular carcinoma," Biomarkers, vol. 14, no. 7, pp. 529-538, 2009.

[193] M. Shigoka, A. Tsuchida, T. Matsudo et al., "Deregulation of miR-92a expression is implicated in hepatocellular carcinoma development," Pathology International, vol. 60, no. 5, pp. 351357, 2010.

[194] L. M. Li, Z. B. Hu, Z. X. Zhou et al., "Serum microRNA profiles serve as novel biomarkers for HBV infection and diagnosis of HBV-positive hepatocarcinoma," Cancer Research, vol. 70, no. 23, pp. 9798-9807, 2010.

[195] J. K. Park, T. Kogure, G. J. Nuovo et al., "miR-221 silencing blocks hepatocellular carcinoma and promotes survival," Cancer Research, vol. 71, pp. 7608-7616, 2011.

[196] E. Callegari, B. K. Elamin, F. Giannone et al., "Liver tumorigenicity promoted by microRNA-221 in a mouse transgenic model," Hepatology, vol. 56, pp. 1025-1033, 2012.

[197] S. Bai, M. W. Nasser, B. Wang et al., "MicroRNA-122 inhibits tumorigenic properties of hepatocellular carcinoma cells and sensitizes these cells to sorafenib," Journal of Biological Chemistry, vol. 284, no. 46, pp. 32015-32027, 2009. 


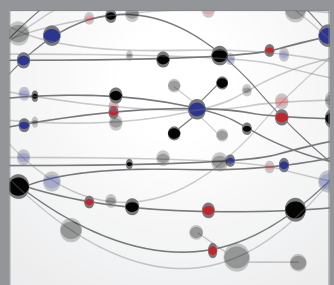

The Scientific World Journal
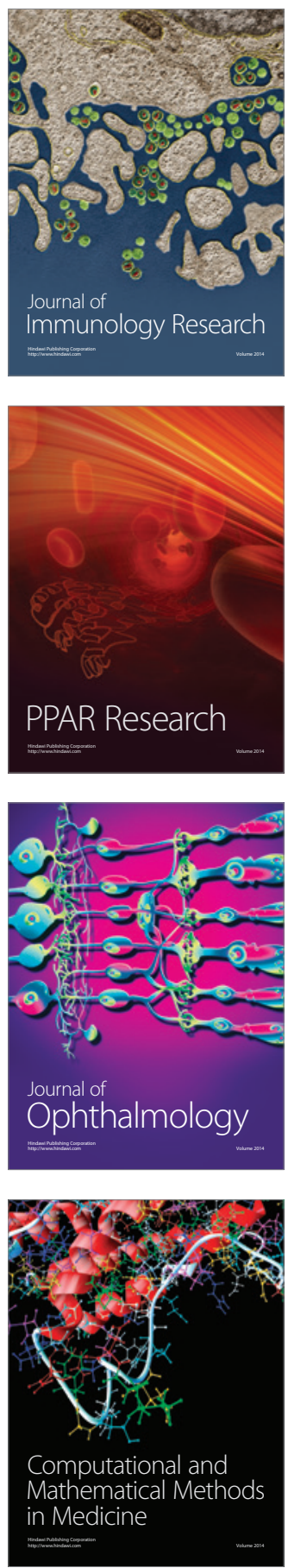

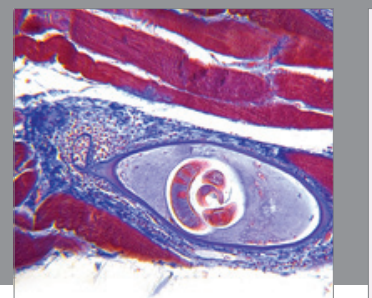

Gastroenterology

Research and Practice
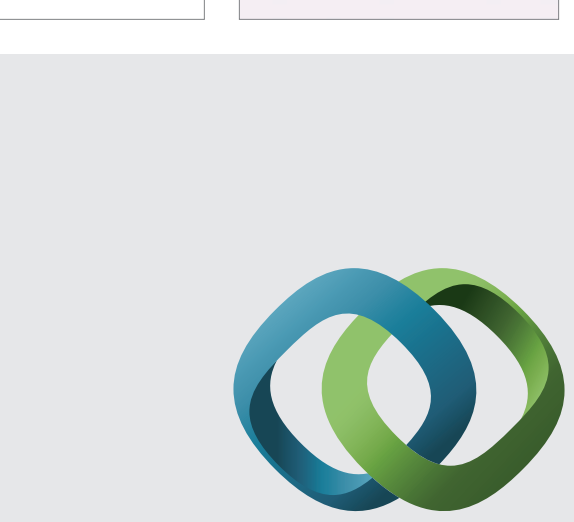

\section{Hindawi}

Submit your manuscripts at

http://www.hindawi.com
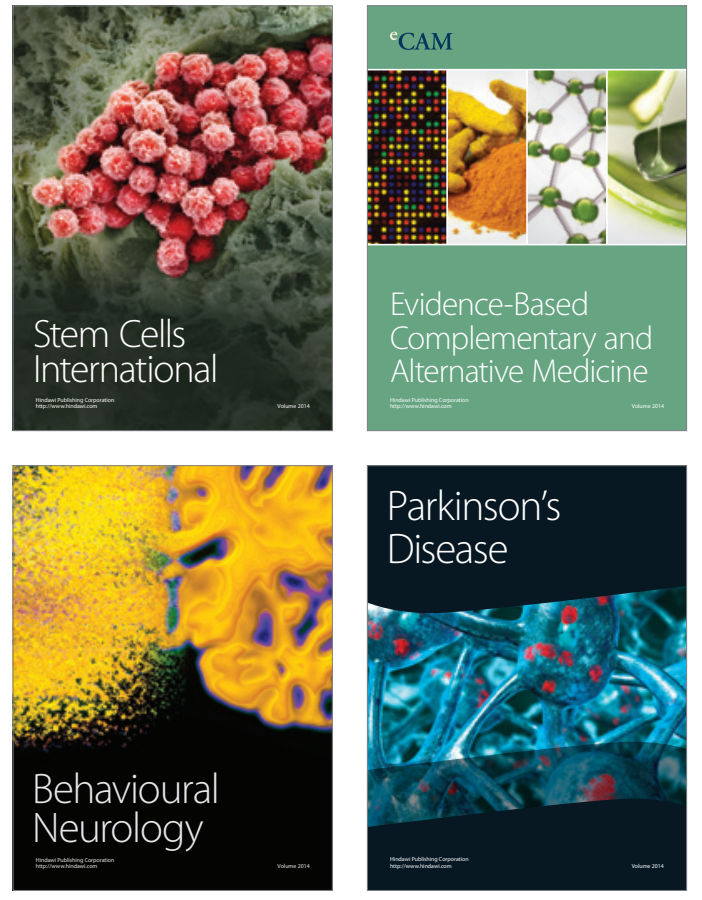
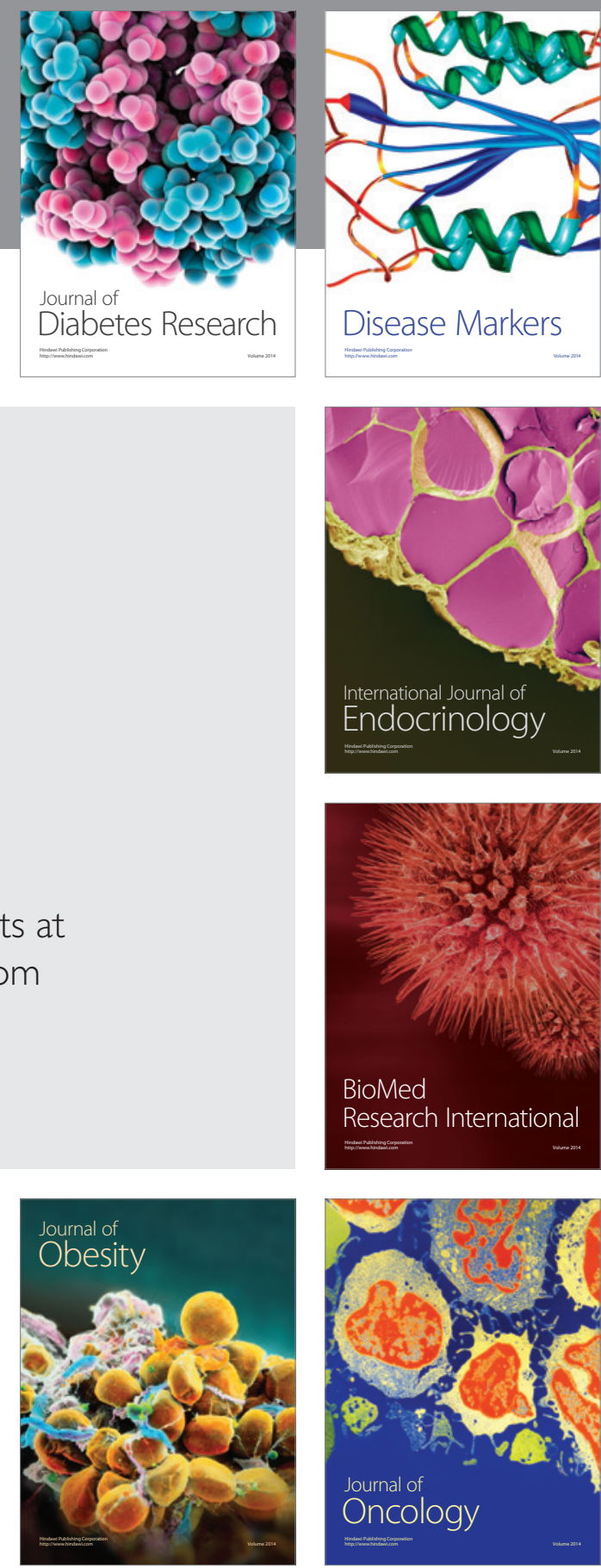

Disease Markers
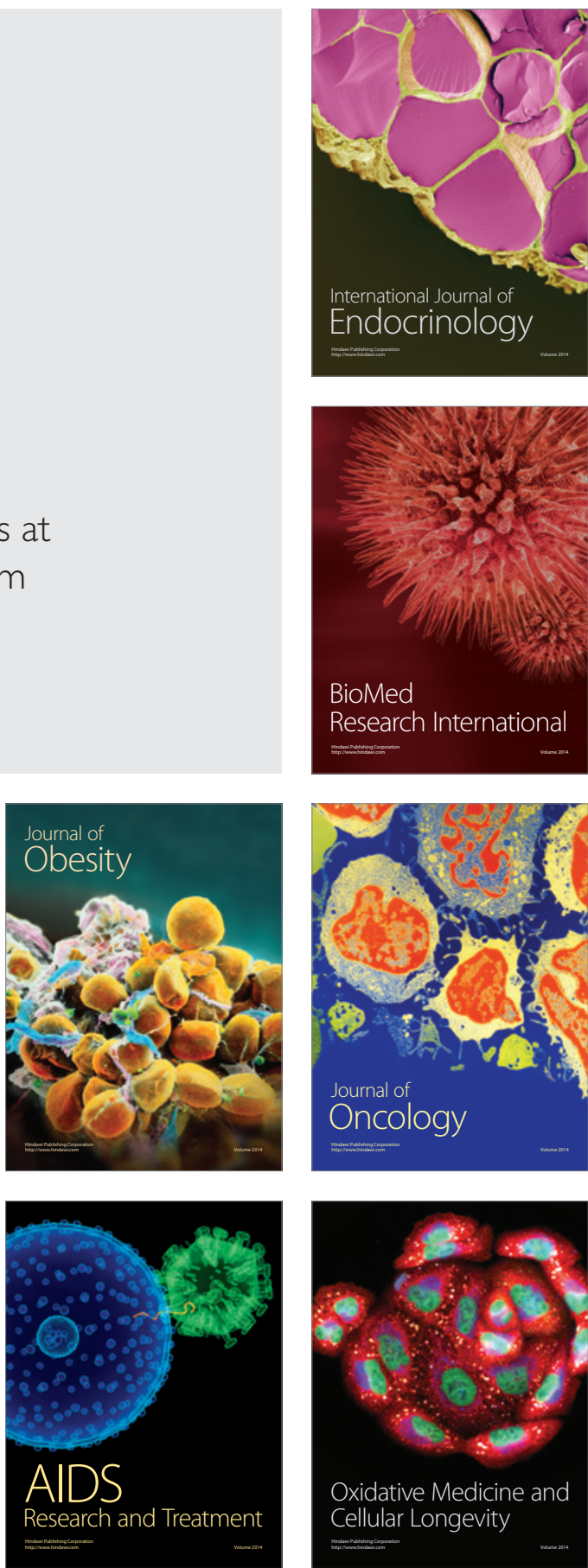